\title{
Article
}

\section{Recovery after Demerger: Evidence from Romanian Companies}

\author{
Constantin Duguleana ${ }^{1}$, Liliana Duguleana ${ }^{2, *}$, Camelia Mirela Baba ${ }^{1}$ and Cristina Drumea ${ }^{1}$ \\ 1 Finance, Accounting and Economic Theory Department, Transilvania University of Brasov, \\ 500036 Brasov, Romania; cduguleana@unitbv.ro (C.D.); mirela.baba@unitbv.ro (C.M.B.); \\ cristina.drumea@unitbv.ro (C.D.) \\ 2 Management and Economic Informatics Department, Transilvania University of Brasov, \\ 500036 Brasov, Romania \\ * Correspondence: ldugul@unitbv.ro; Tel.: +40-726-385-704
}

check for updates

Citation: Duguleana, C.; Duguleana, L.; Baba, C.M.; Drumea, C. Recovery after Demerger: Evidence from

Romanian Companies. Sustainability 2022, 14, 1151. https://doi.org/

$10.3390 /$ su14031151

Academic Editor: Ştefan

Cristian Gherghina

Received: 14 December 2021

Accepted: 18 January 2022

Published: 20 January 2022

Publisher's Note: MDPI stays neutral with regard to jurisdictional claims in published maps and institutional affiliations.

Copyright: (C) 2022 by the authors. Licensee MDPI, Basel, Switzerland. This article is an open access article distributed under the terms and conditions of the Creative Commons Attribution (CC BY) license (https:// creativecommons.org/licenses/by/ $4.0 /)$.

\begin{abstract}
The paper follows the demerger phenomenon in Romania in order to find out whether companies regain their economic performance after reorganization. The research is based on four samples of companies, divided into 2012, 2013, 2014, and 2015, that recorded their financial indicators in the period from 2005-2019. Using the financial indicators of companies that demerged in the same year, we analyzed the economic performances before and after the demergers, using statistical and econometric methods. The model with the fixed effects of the cross sections proved to be the most suitable for each panel, both for the entire analyzed period and for the two subperiods: ante and post demerger. The subperiod models are better than the panel econometric models for the entire period. The results show that all of the Romanian companies recovered after the demergers, and also to what extents. The validities of the econometric models confirm the sustainability of the economic activities after the demergers. This paper provides a study methodology and econometric models to investigate the demerger phenomenon among Romanian companies.
\end{abstract}

Keywords: demerger; financial ratios; panel data models; cross-sectional fixed effects; random effects; heterogeneity

\section{Introduction}

The economic crisis that occurred in 2008 affected the economic activities of Romanian companies, as well as the activities of companies worldwide. The financial crisis started in Romania at the end of 2008, and it resulted in many companies facing difficulties in their activities. Some of them decided to reorganize themselves and proceeded to partial division and reorganization, sooner rather than later, in order to continue to exist.

Companies are merging and dividing all the time in order to obtain better economic results. The 2008 economic crisis was an important reason for making reorganization decisions. The demerger may be seen as the better action in a declining economic framework. The vitality of economic life is ensured by these organizational dynamics, which optimize the allocation of resources and secure an efficient presence in the continuously changing markets.

We consider the financial recovery of demerged companies-financial sustainabilityto be the main element of the economic sustainability of organizations. The financial ratios allow us to interpret the strengths and weaknesses of a company, as well as its historical financial performance. The indicators, such as the ROA, the ROE, the indebtedness, and the net profit margin, describe the links that companies have to the socioeconomic environment, as well as the sustainability of social and corporate governance.

For the Romanian companies that demerged in the years 2012, 2013, 2014, and 2015, we analyzed the internal capabilities and management abilities, comparatively, for the period from 2005-2019, and also for the two subperiods delimited by the demerger years.

In order to characterize the economic performances of all of the Romanian companies that demerged during the period from 2012-2015, we estimated econometric models 
for the four samples, and then we extended the results to the national level. Then, we compared the financial situations before and after the demergers, in two stable subperiods, for all the companies in the samples, i.e., at the beginning and at the end of the analyzed periods: 2005-2011, before the first demerger, and 2016-2019, after the last analyzed year of the demerger.

Econometric panel data models [1] were used to emphasize what happened before and after the demerger years, for each company, and at the panel level. We also built econometric models to compare the performance statuses before and after all the demergers. When we analyzed the results obtained by the four panels, we arrived at some noteworthy conclusions that describe the recent phenomenon of demergers in Romania.

Our work continues with the literature review in Section 2. Section 3, on the methodology, presents the objectives and working hypotheses, the features of the data panels, the aspects of characterizing the financial performances, the econometric framework, as well as the research schedule. Section 4, "Results and Discussion", is structured in four subsections in order to follow the research methodology. The conclusions are set out in Section 5.

\section{Literature Review}

Economists have attentively studied the theories about the changes in organizational structures through mergers and acquisitions, as well as their diversification of core competencies through demergers [2]. More studies are needed in order to treat the merging phenomenon by evaluating the accounting performances before and after mergers [3-5], using the financial ratios, the ROA, the ROE, and the net profit margin, as well as other ratios. The authors studied the information on financial statements and evaluated whether the merger decisions positively affected the economic activities of the envisaged companies, on the basis of their characteristics [6-9].

The demerger is the opposite corporate action, with advantages, but also with downsides [10-12]. The spin-off companies may focus on their core competencies and may ensure, in this way, a better usage of resources. After demergers, companies have their own financial positions, with no cross subsidies. The demerger risks may imply the division of unwanted assets and debts, or the consequences of the new management strategies. The subjective reasons that influence the demerger may also have negative consequences for the spin-off companies [13].

Some authors [14] consider that small innovative enterprises, which split off from big industries or academic bodies, reunite both research and the business environment, and their creation is part of the so-called "academic spin-off", which depicts a special linkage with the concept of sustainability. The creation of such spin-offs is considered by decisionmakers to be "a sustainable base for developing and stimulating business growth". The potential added value that comes from academic research, often unexploited, is seen as a source of interest in the economic world by many authors [15,16]. A dedicated study [16] shows that academic start-up and spin-off companies play a key role in the sustainable economic growth of a region and that they are significant drivers of innovation. In addition to creating new ideas and innovations, such ventures consolidate "an appropriate institutional framework along the whole spin-off value chain" [15].

There is a long experience of demergers among U.S. firms. The scientific literature largely emphasizes the effects of demergers on U.S. companies, as compared to European ones [17]. Moreover, the higher frequency of demergers among U.S. companies partially explains the existing economic development gap between the United States and Europe.

One of the roots of the demerger phenomenon is the antitrust doctrine and the subsequent regulatory measures, particularly in the United States. Early theoretical designs began in the 1950s, with the works of anticonglomerate thinkers $[18,19]$ translated into regulatory policies striving to later avoid the "unilateral effects" — defined as the ability of the merged companies to singularly influence prices in a relevant market—and the "innovation market", which can be translated as the anticompetitive effects of the merger on the research and development in the relevant market [20]. Many critiques have fol- 
lowed [21-25], which state the lack of the theoretical and practical backgrounds needed in order for the cited effects to become economic realities. Pro-demerger and spin-off supporters have appeared as well, showing such phenomena as viable strategic alternatives [26], and arguing that spin-offs "improve the quality of the investment decisions made by managers and reduce the uninformed investors' uncertainty about the value of the resulting divisions". The effect tends to be an "increase of the sum total of the market values of the spun-off divisions above the market value of the original firm" $[27,28]$. The same was observed for the demerger and that is what triggered the current study. There is no doubt that the demerger is a valuable business tactic, particularly in situations of the observed inertia of the parent conglomerate. The example of the Hanson conglomerate, examined in the dedicated study [29], is illustrative in terms of the stock market reaction and the post-demerger long-term performance.

The first research studies presented the performances of companies on the stock market after demerger announcements. The stock market cannot anticipate the value creation at the time of the demerger announcement. One of the first studies was that of Miles and Rosenfeld, published in 1983, about the announcement effects of 55 demergers between 1963 and 1980, which considered the data for 120 trading days before, and for 60 days after, the demergers. In 1983, Schipper and Smith published their analysis of 93 demerger announcements between 1963 and 1981, starting from a period of two days after the demerger announcements [30]. In 1993, Cusatis, Miles, and Woolridge analyzed a sample of 146 demergers between 1965 and 1988, treating a longer time frame: from six months to three years after the demergers [31].

In 2003, Kirchmaier studied the market-based indicators in order to discover the effects of the demerger announcements for a sample of 48 European companies, allowing the comparisons, regardless of the different national accounting systems. The demerged companies were classified as parents and spin-offs, and the analysis period started at one and a half years before, and continued until three years after, the demergers.

Some economists in Germany consider the demerger to be a mania of companies in recent years, and they emphasize that this phenomenon requires some control. They show that the corporations recorded high trading returns after the demergers, and that the insiders significantly gained on the German stock market [32]. They also maintain that demergers do not necessarily solve the deep-rooted problems of companies.

However, the specialists accept that demergers represent a way of handling the lack of performance or the changing economic environment threats [33]. This is an adaptive behavior, meaning that it is a reaction to a perceived threat; however, it can, surprisingly, contribute to building overall stability in the economic environments where it is applied. While sacrificing conglomerate synergies and the advantages of agglutination in order to gain flexibility and the ability to cut out the dead wood, entities from a given economic space create a new equilibrium, at a more granulated level, ensuring sustainability for themselves and for the given industry.

Our research article [34] describes the demerger phenomenon in Romania from 2012-2021, on the basis of descriptive statistical analyses. The structural analysis presents the annual evolution of the 268 demerger projects in Romania, the main sectors of the activities of which they are a part, as well as the reasons and advantages expected through the demerger strategy. The ROA and ROE financial indicators were analyzed for the sample of 72 companies over a period of fifteen years, from 2005-2019. The results of some tests did not show statistically significant differences between the ex-ante and ex-post financial performances of the splits.

This article continues the research on the phenomenon of demergers in Romania on the basis of the same data, using multivariate explanatory methods (econometric panel data models) to analyze the influences of the internal factors on the ROA variation in order to achieve recovery and ensure sustainable economic development. Moreover, we identify the extents to which the demergers determined the ROA variation for four samples of companies, as well as for all demerged Romanian companies, by extending the results of 
the samples. In order to determine whether or not the demerger strategies had positive effects on the economic activities, we analyzed the ROAs of the four panels in two stable subperiods, before and after all the demergers, and we also extended these results to all of the demerged Romanian companies in the analyzed period.

\section{Methodology}

Following the study's primary objective, the derived purposes become its parts, with important outcomes, such as the estimation of the average levels of the ROA financial ratios for all the Romanian demerged companies, as well as the variation influences of its significant factors during the analyzed period and in the subperiods. The research methodology refers to the statistical analyses, sampling methods, and econometric models of panel data obtained using the software, EViews10.

\subsection{Objectives}

The main purpose of our analysis is to evaluate whether the parent firms succeeded in recovering and changing for the better after they agreed to a partial division through a demerger project. Using the ROA as an essential indicator of the economic performance, we estimated it for all of the Romanian companies that demerged in the period from 2012-2015.

The panels are considered in the two separate subperiods: the pre- and post-demerger years. The second subperiod starts in the next year following the demerger, meaning the starting year of a new economic life for the entities that accepted the change. This analysis was undertaken for each panel of demerged companies, and also for the samples of the companies in all four panels.

In order to validate whether or not the demerged companies recovered after the partial division, the results of the ROA analyses for all of the companies of the four panels should at least be at the same level, in the recent common subperiods after the demergers, as well as in those of the earlier common subperiods.

We formulated the following working hypotheses:

Hypothesis 1 (H1) The average annual ROAs of all of the Romanian companies that demerged in the same year is at least the same or higher after the demerger than before it.

Hypothesis 2 (H2) The average annual ROAs of all of the Romanian companies that demerged is at least the same or higher after all the analyzed demergers than in the previous subperiod before all of the demergers.

The econometric models of the four data panels will support the results of the statistical analysis and the ROA confidence intervals obtained by extending the results of the sample research.

Accepting the working hypotheses means that the Romanian companies that demerged managed not only to survive, but also to fully recover and maintain sustainable economic activities.

\subsection{Data Panels}

In the period from 2012-2015, 107 Romanian companies demerged: 31 (29\%) were incorporated share companies, while 76 were limited liability companies, representing $71 \%$ of the total. The companies that demerged in 2012, 2013, 2014, and 2015, and that published their financial indicators for the period from 2005-2019, were included in the four samples [35]. The analysis period (2005-2019) of 15 years was the same for all of the analyzed companies. The panels are named after their demerger years.

The four samples of firms were drawn from the number of all the demerger projects during the period from 2012-2015, from the database of the Romanian Trade Office Registrar [36]. The random character of the sampling was ensured by extracting those companies that recorded financial indicators for the period of 2005-2019, in the demerger projects. 
By analyzing the main activities of the companies (the NACE codes) in the samples, we found a very wide range of activities. Grouping them by activity categories, we concluded that $30 \%$ of them belong to production: $33 \%$ of them are from the food sector, and $67 \%$ from the nonfood sector. In order, the companies engaged in commerce activities represent $19 \%$; the companies involved in various services represent $17 \%$; the transport and related service companies represent $10 \%$; the tourism service companies and those of research and development services each represent $7 \%$; the construction companies represent $6 \%$; and the real estate service companies account for $4 \%$.

The data panels and their characteristics are presented in Table 1. All four of the data panels of the demerged firms $(i=1 \ldots 4)$ are fixed panels; the same firms $\left(n_{i}\right.$ is the volume of panel $i$ ) were observed for each year of the analyzed period, and the panels are balanced. The firms recorded the financial indicators for all the years of the analyzed period, $T=15$. The 2012 panel is the only long panel, with $T>n$, and all the others are short panels, with $T<n$. The sampling ratios vary between $61 \%$ and $76 \%$, and the average of the sampling ratios is $65.4 \%$.

Table 1. The four analyzed data panels.

\begin{tabular}{|c|c|c|c|c|c|c|}
\hline \multirow{2}{*}{$\begin{array}{l}\text { Demerger } \\
\text { Years }\end{array}$} & \multirow{2}{*}{$\begin{array}{l}\text { No. of Demerger } \\
\text { Projects }\left(\mathrm{N}_{\mathrm{i}}\right)\end{array}$} & \multirow{2}{*}{$\begin{array}{c}\text { No. of Firms Selected } \\
\text { in Panel } \\
\left(n_{i}\right)\end{array}$} & \multicolumn{2}{|c|}{$\begin{array}{l}\text { Subperiods of 2005-2019 } \\
\text { (No. in Years) }\end{array}$} & \multirow{2}{*}{$\begin{array}{l}\text { Panel Type: } \\
\text { Long }(T>n) \\
\text { Short }(T<n)\end{array}$} & \multirow{2}{*}{$\begin{array}{l}\text { Sampling } \\
\text { Ratios } \\
n_{i} / \mathrm{N}_{\mathrm{i}}(\%)\end{array}$} \\
\hline & & & $\begin{array}{c}\text { Before } \\
\text { Demerger }\end{array}$ & $\begin{array}{c}\text { After } \\
\text { Demerger }\end{array}$ & & \\
\hline 2012 & 12 & 8 & 8 & 7 & long & $66.7 \%$ \\
\hline 2013 & 33 & 21 & 9 & 6 & short & $63.6 \%$ \\
\hline 2014 & 21 & 16 & 10 & 5 & short & $76.2 \%$ \\
\hline 2015 & 41 & 25 & 11 & 4 & short & $61.0 \%$ \\
\hline 2012-2015 & 107 & 70 & - & - & - & $65.4 \%$ \\
\hline
\end{tabular}

The indicators that we used in the econometric analysis to characterize the financial performances of the companies are: the ROA (the return on assets); the ROE (the return on equity); the indebtedness degree; and the net profit margin. In our econometric approach, we used the ROA as the dependent variable because it is a good indicator of whether or not the resources were effectively used. The explanatory variables, which we consider to be influential on the ROA, are: the ROE, the indebtedness degree, and the net profit margin.

\subsection{Characterizing the Financial Performance}

Some researchers describe the positive and strong relationship between the financial performance and the sustainability [37-39]. The financial performance, in its relationship with sustainability, is influenced by factors such as the company size, measured depending on the asset volumes; the company sector; and the company age [37-39]. The economic sectors have their own coordinates and requirements for social, institutional, and environmental sustainability. There are research studies of specific industries [40], and also of companies across different industries [41]. The financial performance sustainability is ensured when the companies are acting sustainably in order to respond to the expectations of their stakeholders [42]. The age of a company is related to its productivity because of the organizational learning effect manifested in such entities. A longstanding company enjoys a solid reputation, which eventually leads to increased sales, but which can also engrain bureaucracy and lower dynamism, which can negatively influence the financial performance. The characteristics of the behaviors of managers can influence the investments and technological development of companies. New companies can make long-term decisions and develop strategic resources, but the financial resources involved in social responsibility require time to become fruitful [43].

When there are disruptions that unbalance the relationship between the financial performance and the sustainability, then companies decide to break away. The demerger 
is a restructuring process that is usually developed during the mature stage of an entity's lifecycle [43].

The demerger decision is taken when the financial indicators, the ROA, the ROE, the indebtedness, and the net profit margin, reflect the deterioration of a company's economic soundness. The number of employees decreases with the adoption of the demerger strategy. The specific characteristics of the companies, such as the fields of activity, seniority, and the employees, are comprised in the fixed effects of the panel data econometric models; the cross-sectional fixed effects are eliminated (they are annulled at the panel data level), and the common features are modeled.

The profitability ratio, the ROA (the return on assets), with the $\mathrm{ROA}=$ net profit/assets, shows the management's performance in using assets to generate income. The ROA is an essential indicator, allowing for an analyses of the economic and financial activities of a company. It is also used to compare its efficiency levels with those of its competitors within the same industry, embedding, as such, the industry's economic capability, cyclicality, and opportunities. During the low times of economic cycles, the opportunities decrease, and thus, companies within the sector limit their expansion, or even diminish their assets; on the contrary, during the high peaks of economic cycles, expansion accompanies an increase in opportunities in a quest to reach the growing market, and asset acquisition is motivated.

The ROA considers the efficiency of a company's assets. The tendency of the ROA level of evolution is observed over the analyzed period. A higher ROA means a larger capacity for generating income. However, high values of the ROA may be an indication of high risk. An ROA of $5 \%$ or higher is considered a good ratio, with the caveat that the ROA level depends on the similar performances of competitors in the same industry, which is set by the inherent limits of the sector's profitability [44].

The ROA considers the company's fixed assets, but does not consider the intangible assets, such as people, ideas, brand recognition, or intellectual property, which may be valuable in the markets and for investors. For this reason, the ROA cannot always be used to compare one company to another [44].

The profitability is better treated by the ROE (the return on equity) - another profitability ratio, which reflects only the usage of the capital, and not how well the company's assets are utilized. This ratio, $\mathrm{ROE}=$ net profit/equity, informs investors about the capacity of the company to use its capital to generate profits. The ROE shows whether the profitability of the company meets the expectations of the stakeholders. A higher ROE level shows a better management performance in obtaining profit. However, the ROE can be modified by various factors, such as the establishment of a large write-down, or a share repurchase program.

Although the ROE allows investors to identify potentially profitable companies, it has its own disadvantages, and investors should pay more attention to its components. The DuPont model [45] presents the ROE and its drivers. After the 1970s, the DuPont model changed, and the goal shifted from ROA maximization to ROE maximization. DuPont analysis, dated to the 1920s, identifies the ROE's main drivers and how they determine the changes in the ROE [46].

The Dupont model uses a modification for calculating the ROE; it uses a gross value for the assets, where the accumulated depreciation is ignored, instead of a net value. In this way, it renders a higher ROE, and encourages managers to make the most out of the assets by investing in new equipment in order to increase the asset accounts. The ROE three-step identity by DuPont analysis may reveal the nature of the causes of an increasing ROE and their significance [47]. The three components of the ROE after the DuPont method are: the net profit margin (Net profit/Sales Turnover), the asset turnover (Sales Turnover/Assets), and the equity multiplier, also called the "financial leverage" (Assets/Equity). The ROE three-step identity is:

$$
\mathrm{ROE}=(\text { Net profit } / \text { Sales Turnover }) \times(\text { Sales Turnover/Assets }) \times(\text { Assets } / \text { Equity }) .
$$


The net profit margin is one of the key indicators of a company's overall financial status; it is the percentage of the company's profit in the sales turnover. This ratio shows whether the company's management generates enough profit from its sales and covers the costs. The asset turnover shows the asset's rotation, as a measure of the efficiency; it is the ratio between the turnover and the assets. The financial leverage (FL) is the equity multiplier, which equals the ratio between the assets and the equity. When the ROE increases because of the increases in the net profit margin and the asset turnover, then this is a positive aspect of the company. However, the ROE may also increase when the company borrows more money, thereby using a greater amount of financial leverage, an indication that the company is risky for investors [47].

The difference between the ROE and the ROA is the financial leverage or debt. Although the ROE and ROA address different measures of management effectiveness, they are linked, as the DuPont formula shows:

$$
\text { ROE }=\text { Net Profit } / \text { Equity }=(\text { Net Profit } / \text { Assets }) \times(\text { Assets } / \text { Equity })=\mathrm{ROA} \times \mathrm{FL} .
$$

The asset volume represents the sum of the equity and the liabilities, such as debt. The ROA describes the company's capability of making a profit without considering the structure of its capital. The ROA considers a company's debt, and the ROE does not. When a company takes on financial leverage, its ROE is higher than its ROA. Both financial indicators, the ROA and the ROE, are important for shareholders, potential investors, financial analysts, managers, creditors, and others. In the context of companies, the ROA and ROE should be considered together when evaluating the financial performance [47]. A good ROA, a reasonable debt level, and a solid ROE lead to an appreciation of good-quality management in terms of the generation of returns from the investments of shareholders [47].

We use the ROA as the main indicator of financial performance because it shows the company's efficiency in using assets to generate revenues. Assets are an important part of the company's resources, and the ROA provides information about the overall efficiency or overall profitability of a company, with the advantage of also encompassing the inner characteristics of the industry. Since the equity is a part of the assets, when we consider the $\mathrm{ROE}$ as a factor that influences the variation in the ROA, we interpret it as the influence of the profitability of the shareholders' investments on the overall profitability. Debt, as another part of the assets, is considered to have an influence on the overall profitability, using the degree of indebtedness, which is the ratio between the debt and the assets. Following a demerger, a lower volume of assets and a corresponding volume of debt may not significantly affect this ratio. The degree of indebtedness shows how prudently the sources of financing were chosen. The various characteristics of the industries establish the equilibriums of their markets, and the volumes of sales depends on the position of the companies compared to their competitors. The net profit margin is a good indicator for characterizing this aspect for the ROA variation.

As a note, we recall that in the studies [48-50] on mergers, the opposite phenomenon, using the ROA and ROE as the predominant indicators of performance, shows a decrease in the post-merger middle-term indicators, leaving technical, funding, and diversification synergies as the only positive aspects of such endeavors. In the long term, the benefits of higher volumes and better market occupancy may translate into improved performance indicators.

The ROA variable is the best indicator for the characterization of the management capacity for making income, and it is a good indicator of whether or not to look about for a change for the better after demerging. The ROE variable characterizes the management's capacity for making a profit. The higher its value, the better the management performance in generating profit. The net profit margin rate is a good indicator for emphasizing the results of the firm's management performance, in relation to the external conjuncture factors and the forces on the national and the international markets. The indebtedness degree characterizes the debt management. 


\subsection{The Econometric Framework}

When a firm is splitting, it becomes a completely new entity. All the firms in the panels have similar behaviors, and we consider them for the entire analyzed period, from 2005-2019. Hence, the panels are consistent during the entire period because they consider only firms demerging in the same year. We evaluated the poolability of the data in order to use different panel data models.

The panel data of the demerged firms in a certain year has three types of variations: overall, between companies, and within companies, meaning over time. The overall variation is based on the number of observations. The between variation refers to the summary statistics of the number of entities (cross sections), regardless of the time period, and the within variation refers to the summary statistics of the number of years, regardless of the firm.

For this study case, a fixed effects is interpreted as the size of the production capacities of the analyzed firms: each company has its own initial production capacity, and they act on certain markets of goods and services, having specific competition characteristics. The fixed effects refer to a company's internal milieu and they are firm-specific effects. The random effects envisage the aspects of a company's interactions with the external milieu, and they may include the following: the stability of the production against fluctuations; the characteristics of the external environment; the market conditions; the network relationships; the openness; and the economic conjuncture.

The panel data models may consider the heterogeneity at the cross-sectional level, or over a time period (one-way models), or in both dimensions (two-way models), and may separate them as specific effects [51-53]. The errors of the panel data regression models have the following structure: the cross-sectional part, the time part, and the error part, at the level of each observation. The types of panel data models depend on how they consider the error term structure, as well as on their interaction approaches to the regression equation.

The pooled OLS model of firms neglects both the nature of the time series and of the cross-sectional data. The pooled OLS model is also called the "common effects" model (Equation (1)). For modeling the panel data, the pooled OLS model may produce efficient and consistent estimators of the parameters if there are no individual effects of the crosssectional nature and time. All these effects are comprised in the error term:

$$
y_{i t}=\alpha+X^{\prime}{ }_{i t} \beta+\varepsilon_{i t},
$$

where $y_{i t}$ is the dependent variable for the cross section, $i$, at time, $t ; X_{i t}^{\prime}$ is the array of independent variables for the cross section, $i$, at time, $t ; \alpha$ is the intercept for all the cross sections; $\beta$ is the coefficient (slope) for the independent variable, $X_{i t}$; and $\varepsilon_{i t}$ is the error term.

The pooled OLS model assumes no heterogeneity, and the intercept, $\alpha$, and the slope, $\beta$, are common and the same for all the cross sections. The pooled regression model cannot be used because the firms, i.e., the cross sections, are not homogenous.

The heterogeneity, which may or may not be observed, can be identified using the panel data models with either firm-specific effects, time effects, or both types. These types of effects are either fixed or random effects.

For the fixed effects, the regression models with dummy variables corresponding to the effect types are used. The panel model with the fixed effects of individual cross sections or entities in Equation (2) is estimated by the least squares dummy variable model (LSDV), which is a regression OLS with a set of dummies for the intercepts of the firms, $u_{i}$ :

$$
y_{i t}=\left(\alpha+u_{i}\right)+X_{i t}^{\prime} \beta+v_{i t}
$$

The panel model with the fixed effects of the time periods is estimated by the within effect estimation methods. The model of the fixed effects within the group estimator is the regression with the fixed effects on the demeaned variables. In this way, the fixed effects, or the intercept terms, of the individual effects drop out. 
The random effects models prove to be more efficient than the fixed effects models because they estimate the effects of the variables, which are constant at the cross-sectional level, and do not vary "within" them, over time. The panel model with the random effects of the entities is represented in Equation (3):

$$
y_{i t}=\propto+X^{\prime}{ }_{i t} \beta+\left(u_{i}+v_{i t}\right)
$$

While the fixed effects model describes the intercepts varying across firms or over time periods, the random effects model looks for the differences in the error variance components across firms or over time periods. The random effects model eliminates the heteroscedasticity, and it is also called the "error component model" [54].

The heterogeneity that is caused by the unobserved variables or the omitted relevant variables produces fixed and random effects, inducing biases in the pooled OLS. The unobserved heterogeneity can be attributed to the intercept or to the error variance component. The main issue is whether the individual specific error component is related to the regressors [55].

The F-test for fixed effects evaluates the significances of the dummy variables in the LSDV model compared to the OLS model. The null hypothesis $\left(\mathrm{H}_{0}\right)$ is that the dummy parameters are all zero, and the alternative hypothesis $\left(\mathrm{H}_{1}\right)$ maintains that at least one dummy parameter is not zero. If the $\mathrm{H}_{0}$ is rejected, then there exists at least one firm or time-specific intercept, $u_{i}$, that is not zero, meaning that there is a significant fixed effect, which contributes to the goodness-of-fit in the fixed effects model compared to the pooled OLS model.

The random effects model assumes that the individual effects (heterogeneity) are not correlated with any regressor [56].

The Breusch-Pagan LM test for random effects uses the Lagrange multiplier (LM) to test for the existence of homoscedasticity in the $\mathrm{H}_{0}$, i.e., it tests whether the individual or time-specific variance components are zero: $\sigma_{u}^{2}=0$. If the $\mathrm{H}_{0}$ is rejected, then the panel data has significant random effects; the random effect model is better at explaining the heterogeneity than the pooled OLS model.

The Hausman test is used to select the better model between the fixed effects model and the random effects model. The random effects model is preferred over its corresponding fixed effects model, when is not rejected the $\mathrm{H}_{0}$ of the individual effects uncorrelated with any regressor.

In both the fixed and random effects models, the slopes remain constant, and only the intercepts and error variances change. The poolability is a concept used when the slopes are the same across entities or over time [57]. A poolability test is an extension of the Chow test, with the $\mathrm{H}_{0}$ maintaining that the slope of the regressor is the same for all the cross sections, and for all the $k$ regressors, $\beta_{i k}=\beta_{k}$. If the $\mathrm{H}_{0}$ is rejected, the panel data is not poolable, meaning that each entity (individual) has its own slopes for all the regressors. Baltagi suggests an alternative test of poolability, which consists of proving the existence of individual effects [57]. He proposes the F test to evaluate the poolability of panel data with a null hypothesis for the pooled OLS model, and as its alternative for the fixed effects model. If the statistic, F, is insignificant, then the cross sections are homogeneous, and no panel model is needed.

The cross-sectional dependence and the contemporaneous correlations (bias in the test results) represent some problems that need solving. The Pesaran CD test (cross-sectional dependence) evaluates whether the residuals are correlated across entities (cross sections), and its null hypothesis is that the residuals are not correlated.

\subsection{Research Schedule}

The "Results and Discussion" section of the research study is structured into four sections that approach the variations in the performance indicator, the ROA. The statistical analysis of the real data, along with the econometric modeling for the entire period, 
from 2005-2019, envisage the comparative presentation of the pre- and post-demerger subperiods.

The first section compares the evolution of the average ROAs of the panels for the period from 2005-2019, and the average ROAs of the panels over the corresponding subperiods, before and after the demergers. The statistical analysis for each panel of companies is extended to all the companies that demerged in the same year, with a probability of $95 \%$.

In the second section, the identified econometric models of the data panels for the whole period are compared, with the results of the same type of model applied to the anteand post-demerger subperiods. This section consists of obtaining the best econometric models for the datasets presented in the first section. The first two sections will verify the hypothesis, $\mathrm{H} 1$.

In the third section, we compare the ROA development stages for all the companies in all the four panels during the two stable subperiods. To see the ROA stages of the companies before any demergers, we chose the earliest common subperiod: 2005-2011. The second subperiod, after all the demergers, is 2016-2019, and the last most recent subperiod is at the end of the analyzed period, from 2005-2019. We compared the average levels of the ROAs of companies that demerged, using these subperiods, before and after the demerger actions. The results are extended, in terms of the population, to all the Romanian companies that demerged in the period from 2012-2015, with a probability of $95 \%$.

The fourth section presents the modeling phase, which is based on the appropriate econometric approach for the analyzed datasets of the third phase. The third and the fourth sections address the hypothesis, $\mathrm{H} 2$.

The first and third sections contain statistical analyses of the data panels for the whole period and certain established subperiods. Both sections contain the extension of the results of the data panels to all Romanian companies in the demerger years in the period from 2012-2015. The second and fourth sections present the econometric models in Eviews10, which correspond to the analysis of the data from each corresponding previous section.

Synopses of the full period and of the significant subperiods for each panel are presented in Sections 4.1 and 4.2. The analyses of the whole period and the two stable sub-periods for all panels are presented in Sections 4.3 and 4.4. The sampling results are extended to the population level for all the Romanian companies that demerged in the period from 2012-2015, in Sections 4.1 and 4.3. There is a symmetry in combining the statistical analysis with the econometric modeling of each panel in Sections 4.1 and 4.2, and in Sections 4.3 and 4.4 .

\section{Results and Discussion}

4.1. Statistical Analysis of the ROAs of Companies for the Period from 2005-2019, and the Corresponding Subperiods

The ROA statistics of the four panels of the demerged companies are presented in Tables 2 and 3. The panels are analyzed for the whole period, from 2005-2019, in Table 2, and for the two subperiods, before and after the demergers, in Table 3.

For all the panels, the average annual ROAs are between 5\% in the 2012 panel and $9.4 \%$ in the 2015 panel, in Table 2. The average annual ROAs increase from one panel to another over time. This trend of increasing ROAs over time can be explained by the longer periods of existence of the companies before the demergers, within each panel.

In order to extend the results of the sample to the population of all companies demerged in a certain year, we calculated the limit error of the ROA, $\Delta_{\mathrm{ROA}}$, with a probability of $95 \%$, to establish the ROA confidence intervals for all the Romanian companies that demerged from 2012-2015, in Table 2.

On the basis of the four panels (last column of Table 2), we found that, for the period from 2005-2019, all the Romanian companies that demerged in 2012-2015 had annual average ROAs in a range between $7.3 \%$ and $8.8 \%$, with a probability of $95 \%$. Over time, the lower and upper limits of the ROA confidence intervals increased, describing an upward trend in the average ROA values. However, we are interested in the average values of the 
ROAs in the ante and post subperiods of the demerger years, rather than in the values of the average annual ROAs for the entire period covering the years of the demergers.

Table 2. ROA statistics of the panels and the samples of all demerged companies, from 2005-2019.

\begin{tabular}{cccccc}
\hline ROA & 2012 Panel & 2013 Panel & 2014 Panel & 2015 Panel & All Panels \\
\hline Mean & $5.0 \%$ & $6.5 \%$ & $8.9 \%$ & $9.4 \%$ & $8.1 \%$ \\
\hline Median & $1.8 \%$ & $3.5 \%$ & $3.2 \%$ & $4.0 \%$ & $3.5 \%$ \\
\hline Maximum & $173.0 \%$ & $86.0 \%$ & $97.1 \%$ & $188.8 \%$ & $188.8 \%$ \\
\hline Minimum & $-113.8 \%$ & $-83.9 \%$ & $-49.8 \%$ & $-21.0 \%$ & $-113.8 \%$ \\
\hline Std. Dev. & $26.7 \%$ & $20.7 \%$ & $16.2 \%$ & $17.7 \%$ & $20.0 \%$ \\
\hline Observations & 120 & 315 & 240 & 375 & 1050 \\
\hline No. of firms $(n)$ & 8 & 21 & 16 & 25 & 70 \\
\hline Limit error, $\Delta_{\mathrm{ROA}}$ & $2.8 \%$ & $1.4 \%$ & $1.0 \%$ & $1.1 \%$ & $0.7 \%$ \\
\hline Lower limit, $95 \%$ & $2.2 \%$ & $5.1 \%$ & $7.9 \%$ & $8.3 \%$ & $7.3 \%$ \\
\hline Upper limit, $95 \%$ & $7.7 \%$ & $7.9 \%$ & $9.9 \%$ & $10.5 \%$ & $8.8 \%$ \\
\hline
\end{tabular}

Table 3. ROA statistics of panels and of all demerged Romanian companies in the two corresponding subperiods, from 2005-2019.

\begin{tabular}{ccccccccc}
\hline \multirow{2}{*}{ ROA } & \multicolumn{2}{c}{$\mathbf{2 0 1 2}$ Panel } & \multicolumn{2}{c}{ 2013 Panel } & \multicolumn{2}{c}{ 2014 Panel } & \multicolumn{2}{c}{ 2015 Panel } \\
\cline { 2 - 9 } & $\mathbf{2 0 0 5 - 2 0 1 2}$ & $\mathbf{2 0 1 3 - 2 0 1 9}$ & $\mathbf{2 0 0 5 - 2 0 1 3}$ & $\mathbf{2 0 1 4 - 2 0 1 9}$ & $\mathbf{2 0 0 5 - 2 0 1 4}$ & $\mathbf{2 0 1 5 - 2 0 1 9}$ & $\mathbf{2 0 0 5 - 2 0 1 5}$ & $\mathbf{2 0 1 6 - 2 0 1 9}$ \\
\hline Mean & $9.4 \%$ & $-0.2 \%$ & $5.3 \%$ & $8.3 \%$ & $7.4 \%$ & $11.8 \%$ & $9.8 \%$ & $8.3 \%$ \\
\hline Median & $2.0 \%$ & $1.2 \%$ & $3.0 \%$ & $3.8 \%$ & $2.4 \%$ & $5.3 \%$ & $4.1 \%$ & $3.9 \%$ \\
\hline Maximum & $173.0 \%$ & $87.6 \%$ & $84.8 \%$ & $86.0 \%$ & $56.9 \%$ & $97.1 \%$ & $188.8 \%$ & $70.1 \%$ \\
\hline Minimum & $-76.3 \%$ & $-113.8 \%$ & $-83.9 \%$ & $-56.4 \%$ & $-13.7 \%$ & $-49.8 \%$ & $-12.2 \%$ & $-21.0 \%$ \\
\hline Std. Dev. & $27.1 \%$ & $25.5 \%$ & $22.3 \%$ & $18.0 \%$ & $12.3 \%$ & $21.9 \%$ & $18.5 \%$ & $15.1 \%$ \\
\hline Observations & 64 & 56 & 189 & 126 & 160 & 80 & 275 & 100 \\
\hline Limit error 95\% & $3.9 \%$ & $3.9 \%$ & $1.9 \%$ & $1.9 \%$ & $0.9 \%$ & $2.4 \%$ & $1.4 \%$ & $1.9 \%$ \\
\hline Lower limit CI 95\% & $5.6 \%$ & $-4.1 \%$ & $3.4 \%$ & $6.4 \%$ & $6.5 \%$ & $9.4 \%$ & $8.4 \%$ & $6.5 \%$ \\
\hline Upper limit CI 95\% & $13.3 \%$ & $3.7 \%$ & $7.2 \%$ & $10.2 \%$ & $8.3 \%$ & $14.1 \%$ & $11.2 \%$ & $10.2 \%$ \\
\hline
\end{tabular}

Table 3 contains the ROA statistics, corresponding to the subperiods before and after the demergers, for each panel. The extension of the sample results of each panel, and for each subperiod, to the level of all Romanian companies demerged in 2012, 2013, 2014, and 2015, is also presented in Table 3.

Looking to the average values of the ROAs, we see that, in the 2012 panel, the ROAs decreased intensely after the demergers, but, for the 2013 and 2014 panels, the average ROAs increased after the demergers. For the 2015 panel, the average values of the ROAs after the demergers are slightly lower than before, but are still around $8 \%$, although the number of analyzed years after the demergers is only four years. We can conclude that, after an interval of at least five years, the demerging Romanian companies were finally recovering.

The two panels that stand out are the 2014 and 2012 panels in Table 3. The 2014 panel presents a post-demerger ROA average of $11.8 \%$ and a standard deviation of $21.9 \%$, while the ante-demerger average ROA was $7.4 \%$, with a standard deviation of $12.3 \%$. The 2012 panel had a post-demerger average ROA of $-0.2 \%$ and a standard deviation of $25.5 \%$, while the ante-demerger average ROA was $9.4 \%$, with a standard deviation of $27.1 \%$. As the standard deviation is the measure of the variation of the dataset from its mean, it 
provides the variability of a distribution. In the case of the 2012 panel, we observe the large amplitude of the deviation from the mean value.

In the subperiod after the demergers, the companies that demerged in 2012 recorded a decrease in the ROAs, for which the confidence intervals, with $95 \%$ probability, are $-4.1 \%$ and $3.7 \%$. Much better situations in the subperiod after the demergers were recorded by the companies that demerged in 2013, with confidence intervals of the average ROAs of $6.4 \%$ and $10.2 \%$, and, in 2014 , of $9.4 \%$ and $14.1 \%$. The confidence intervals of the average ROAs in the post-demerger subperiod of the 2015 panel are $6.5 \%$ and $10.2 \%$, with both limits lower than in the ante-demerger subperiod, but still in a good situation because the second subperiod was shorter.

On the basis of the extension of the results of the ROA statistical analysis of each panel in each ante- and post-demerger subperiod, we can accept the hypothesis, H1, as true.

\subsection{ROA Econometric Modeling of Panels over the Period and in the Ante- and Post-Demerger Subperiods}

4.2.1. Econometric Approaches of the Data Panels for the Entire Period, from 2005-2019

In order to model the data panels of the companies in the sample for the period from 2005-2019, we used EViews10 software. We refer to the ROA as the dependent variable and, for the explanatory variables, we consider the influencing factors: the ROE, the ability of management to make a profit; the INDBT_DG, the degree of indebtedness; and the PR_MG, the net profit margin.

The variables considered were cointegrated for each panel, which was concluded after using the panel cointegration test. With the Granger causality analysis, we tested the separate significances of each variable and the joint significances of the explanatory variables for the dependent variable, the ROA. For all the data panels, we considered the ROE, the INDBT_DG, and the PR_MG as significant explanatory variables for the ROA variation, except for the 2014 panel. The variable, INDBT_DG, was not significant for the ROA variation in the 2014 panel data, and we used only the ROE and the PR_MG as the explanatory variables.

Applying the Chow test, also called the "redundant variable test", we may evaluate whether each explanatory variable in the model is significant, as well as whether they are jointly significant for the ROA variation. We also applied poolability tests. The restricted model is the pooled OLS model, and the unrestricted model is the fixed effects model for either cross sections or for the periods, or for both types of effects. The redundant fixed effects tests show the significances of the fixed effects for each of the three dimensions. We may evaluate whether the cross-sectional effects, the period fixed effects, or both the cross-sectional and the period fixed effects are redundant or significant.

For all the models, we found that the fixed effects model (FE) is better than the OLS pooled model. The pooled model (OLS) is restricted because it neglects the heterogeneity effects, which are considered by the model with the fixed effects. The tests for the individual cross-section and period effects, and then, simultaneously, for both types of effects, confirm that the FE model of cross-sections is superior to the pooled regression. We concluded that the effects of cross-sections are significant, but that the effects of the periods and of both simultaneous fixed effects of the cross sections and periods are redundant. The heterogeneity of individuals, here, the companies, is reflected in the cross-sectional effects, and these effects are important for the demerger analysis.

The Lagrange multiplier (LM) evaluates whether the panel data recognize the significances of the cross-sectional random effects. The Breusch-Pagan test indicates crosssectional, as well as both cross-sectional and period, random effects. By applying the Hausman test, we found that the fixed effects models of cross sections are superior to the random effects models.

The dependence cross correlation in residuals is not a problem for the short panels and, for all the models, the Pesaran $\mathrm{CD}$ accepts the $\mathrm{H}_{0}$ of the non-cross-sectional dependence. The cross-sectional fixed effects are significant for each demerger panel. 
The results of analyzing the significances of the fixed and random effects are presented in Table 4. The column of the cross-sectional FE models is emphasized as being the best choice.

Table 4. Identifying the significant effects of the data panel models for ROAs in the period from 2005-2019.

\begin{tabular}{lcccccc}
\hline $\begin{array}{l}\text { ROA-Dependent } \\
\text { Variable }\end{array}$ & \multicolumn{3}{c}{ Fixed Effects (FE) } & & Random Effects (RE) \\
\hline Demerge Year & Cross Section & Time & $\begin{array}{c}\text { Cross Section } \\
\text { and Period }\end{array}$ & $\begin{array}{c}\text { Cross Section } \\
\text { Time }\end{array}$ & $\begin{array}{c}\text { Cross Section } \\
\text { and Period }\end{array}$ \\
\hline 2012 & $\sqrt{ }$ & - & - & $\sqrt{ }$ & - & $\sqrt{ }$ \\
\hline 2013 & $\sqrt{ }$ & - & $\sqrt{ }$ & $\sqrt{ }$ & - \\
\hline 2014 & $\sqrt{ }$ & - & $\sqrt{ }$ & $\sqrt{ }$ & - & $\sqrt{ }$ \\
\hline 2015 & $\sqrt{ }$ & - & $\sqrt{ }$ & & $\sqrt{ }$ \\
\hline
\end{tabular}

The significant cross-sectional and period fixed effects can be explained by the fact that all the companies in the same sample demerged in the same year. The combined influences of the characteristics and common behaviors of the companies over time are sufficiently important to be, together, recognized as significant.

\subsubsection{Analyzing the Short- and Long-Run Aspects of ROA Evolution}

The ROA variable is a nonstationary variable, and it has a unit root for each panel. We decomposed the ROAs into trends and cycles. The cross-sectional and period fixed effects are part of the long-term evolution (trend), which we determined with a filter for the ROAs. We used a Corbae-Ouliaris FD Filter (2006) in Eviews to find the ROA_FD. The cycle is the difference between the ROA and its trend, the ROA_FD. We analyze the ROA long-run (ROA_FD) and short-run fluctuations (CYCLE) [58] in Figure 1.

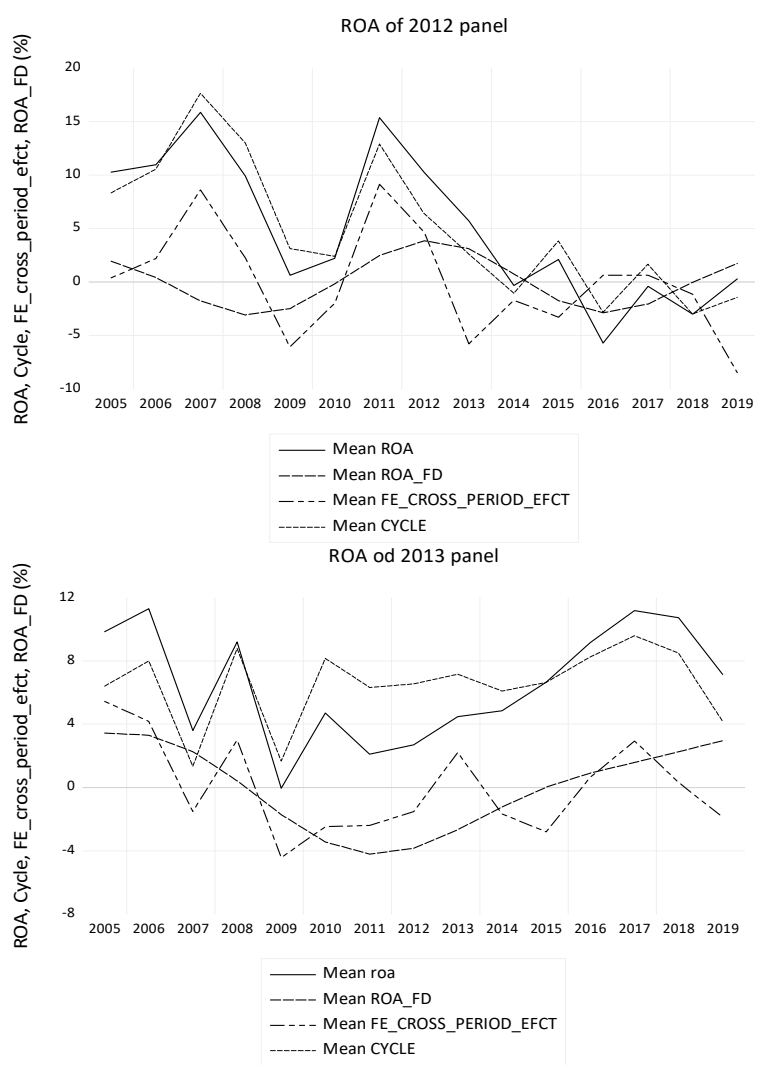

Figure 1. Cont. 

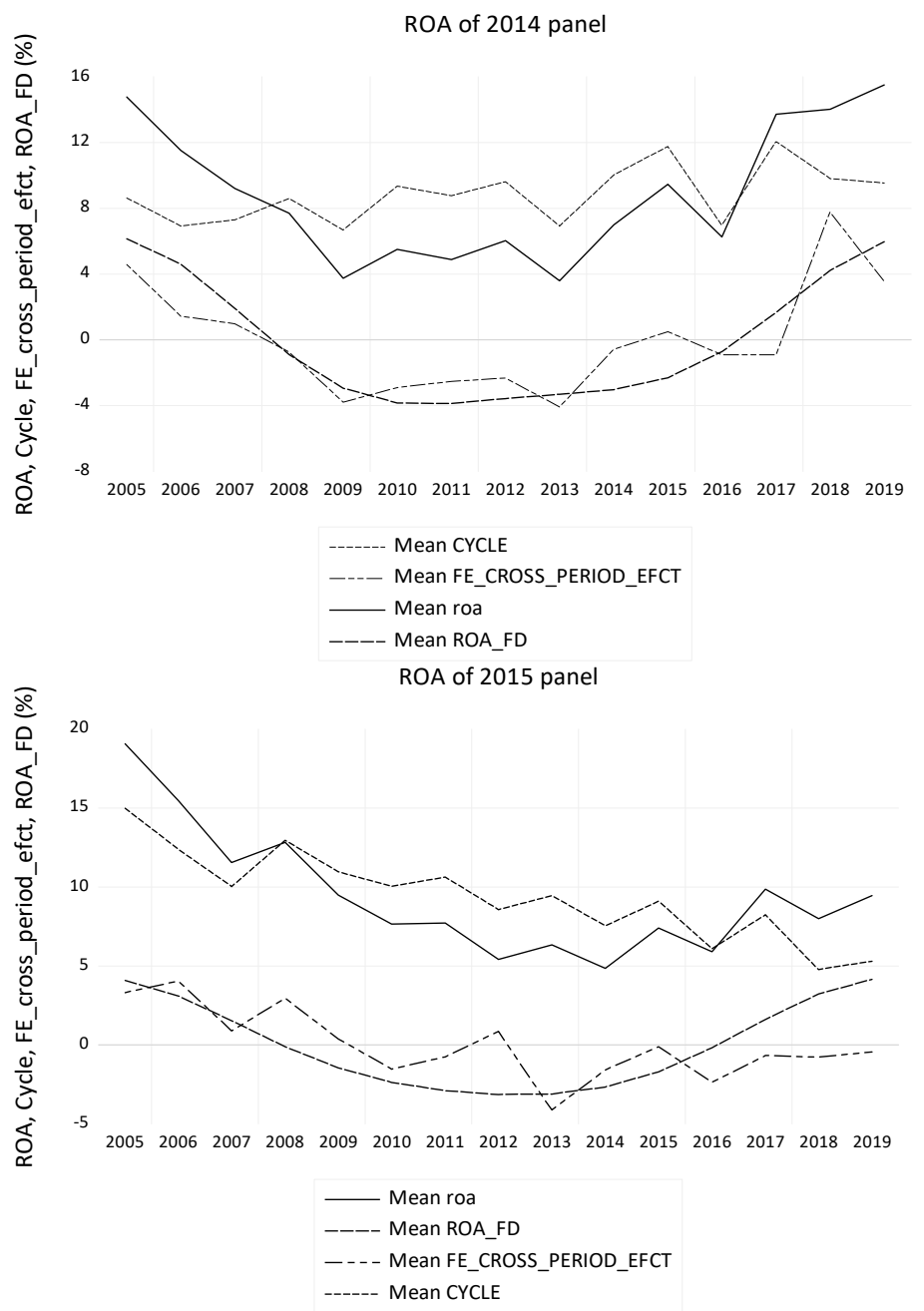

Figure 1. ROAs, cycles, trends, and cross-sectional and period fixed effects for each panel.

The filtered values, called the ROA_FD, in Figure 1, have a similar evolution for the panels from 2013, 2014, and 2015, with the most negative values in one year during the period from 2010-2011, and varying in the range between $-3.8 \%$ and $4-6.2 \%$, depending on the demerger panel. We see in Table 4 that the cross-sectional and period fixed effects are not significant in the FE model for the 2012 panel. Still, we keep it in our analysis.

Using the two-way FE model for each panel, we obtained the fixed effects of both the cross sections and the times (periods), which include the long-term trends of the ROA (ROA_FD), as seen in Figure 1. The influence of long-run ROA growth is comprised in the fixed effects of the cross sections and periods, as presented in Figure 1.

Except for the 2012 panel, we see, in Figure 1, that the cycle component intersects and exceeds the ROA in 2008, before the start of the economic crisis at the end of the year, in each of the other panels. We see that, after the demerger year, this intersection appears at two years for the 2012, 2013, and 2014 panels and after one year for the 2015 panel. The ROAs grow and exceed the business cycles, which remain below the ROA. It is considered that recovery is achieved in the following year after the ROA exceeds its cycle. The conclusion is that, after a period of 2-3 years, the ROA should recover after the split.

The two point years of the intersection between the ROA and its own business cycle determine a period, starting with 2008, when the cycles are over the ROAs, and companies have to find a restructuring solution: the demerger.

The full recovery should be considered achieved when the real economic cycle is taken into account. The economic cycle is considered in the macroeconomic aggregate variables to be the regular fluctuations in the periods of expansion and contraction. 
The ways in which the companies act are in line with the macroeconomic aggregate activities and, for this reason, we cannot take into account the GDP growth rates in the models. However, we can compare, analyze, and interpret the influence of the real business cycles on the observed changes in the ROAs of companies.

We filtered the GDP growth rates with a Corbae-Ouliaris FD filter, and we compare the real business cycles with the ROAs filtered from each panel in Figure 2.

GDP growth rates, real business cycle and ROA of 2012 panel

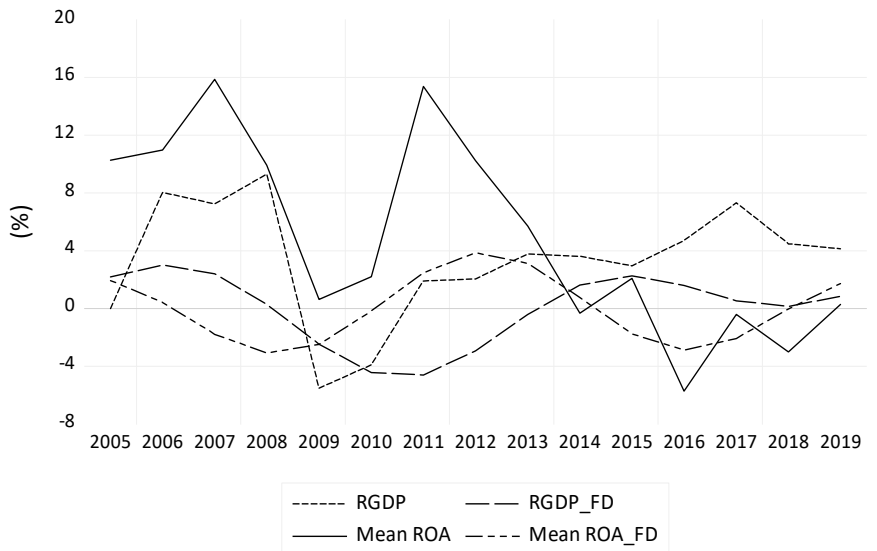

GDP growth rates, real business cycle and ROA of 2014 panel

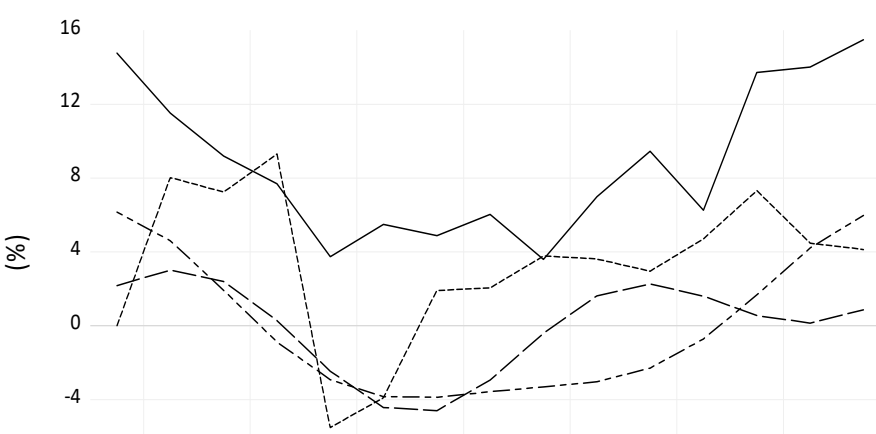

-8 200520062007200820092010201120122013201420152016201720182019

$$
\begin{array}{ll}
\text {---- RGDP } & - \text { RGDP_FD } \\
- \text { Mean ROA } & --- \text { Mean ROA_FD }
\end{array}
$$

GDP growth rates, real business cycle and ROA of 2015 panel

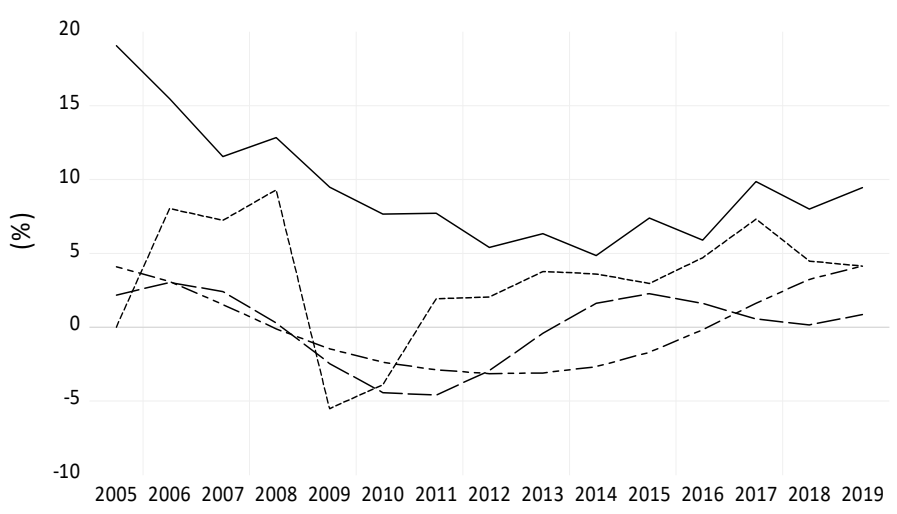

$$
\begin{array}{ll}
---R^{-} \text {RGDP } & - \text { RGDP_FD } \\
- \text { Mean ROA }--- \text { Mean ROA_FD }
\end{array}
$$

Figure 2. Integrating the real business cycles into the ROAs of each panel. 
We note that, especially for the 2013, 2014, and 2015 panels, the real business cycles and long-term ROAs have a similar evolution from 2005 to 2010-2011, and then the ROA trends of the panels remain below the real business cycles, providing the signal for necessary change.

The financial recoveries of companies after demergers are achieved when the ROA trends of the panels intersect and exceed the real business cycles, as the newly structured companies are in the expansion phase.

We used an analysis of the short-term changes of the ROAs and their own cycles for each panel. We performed a long-term analysis, comparing the influence of the real business cycles on the long-term ROAs of each panel. The results are roughly similar for both short-term and long-term developments.

4.2.3. Econometric Models of Data Panels for 2005-2019, with the Influence of the Demerger Year

For all the panels, cross-sectional fixed effects models are the best choice. The influences of the characteristics of the companies represent the cross-sectional fixed effects.

In order to emphasize the effects of the demergers, we used dummy variables, with values of 0 in the years before the demerger subperiod, and with values of 1 in the years of the subperiod after the demergers. The results are presented in Table 5.

Table 5. The cross-sectional FE models of the panels for the period from 2005-2019.

\begin{tabular}{|c|c|c|c|c|}
\hline \multirow{2}{*}{$\begin{array}{l}\text { FE Cross Section with } \\
\text { Dummy Variables }\end{array}$} & \multicolumn{4}{|c|}{ 2005-2019 } \\
\hline & 2012 Panel & 2013 Panel & 2014 Panel & 2015 Panel \\
\hline ROA-dependent variable & $\mathrm{a}_{\mathrm{i}}^{* * *}$ & $a_{i}^{* * *}$ & $\mathrm{a}_{\mathrm{i}}^{* * *}$ & $a_{i}^{* * *}$ \\
\hline $\mathrm{C}$ & $\begin{array}{c}0.111 \\
(0.020) \\
\end{array}$ & $\begin{array}{c}0.181 \\
(0.011) \\
\end{array}$ & $\begin{array}{c}0.105 \\
(0.014) \\
\end{array}$ & $\begin{array}{c}0.037 \\
(0.003) \\
\end{array}$ \\
\hline ROE & $\begin{array}{c}0.106 \\
(0.020)\end{array}$ & $\begin{array}{c}0.025 \\
(0.004)\end{array}$ & $\begin{array}{c}0.071 \\
(0.020)\end{array}$ & $\begin{array}{c}0.270 \\
(0.012)\end{array}$ \\
\hline INDBT_DG & $\begin{array}{l}-0.138 \\
(0.027)\end{array}$ & $\begin{array}{l}-0.237 \\
(0.020)\end{array}$ & $\begin{array}{l}-0.089 \\
(0.020)\end{array}$ & $\begin{array}{l}-0.030 \\
(0.007)\end{array}$ \\
\hline PR_MG & $\begin{array}{c}0.347 \\
(0.036)\end{array}$ & $\begin{array}{c}0.021 \\
(0.005)\end{array}$ & $\begin{array}{c}0.392 \\
(0.052)\end{array}$ & $\begin{array}{c}0.296 \\
(0.026)\end{array}$ \\
\hline $\mathrm{DUM} \times \mathrm{ROE}$ & $\begin{array}{l}-0.078 \\
(0.020)\end{array}$ & - & $\begin{array}{l}-0.066 \\
(0.020)\end{array}$ & $\begin{array}{c}0.167 \\
(0.024)\end{array}$ \\
\hline DUM × INDBT_DG & - & $\begin{array}{c}0.043 \\
(0.012)\end{array}$ & $\begin{array}{c}0.051 \\
(0.012)\end{array}$ & $\begin{array}{l}-0.017 \\
(0.005)\end{array}$ \\
\hline DUM $\times$ PR_MG & $\begin{array}{l}-0.324 \\
(0.036)\end{array}$ & $\begin{array}{c}0.067 \\
(0.023)\end{array}$ & $\begin{array}{l}-0.194 \\
(0.053)\end{array}$ & $\begin{array}{l}-0.241 \\
(0.029)\end{array}$ \\
\hline $\mathrm{R}^{2}$ & $85.6 \%$ & $61.9 \%$ & $79.3 \%$ & $91.7 \%$ \\
\hline
\end{tabular}

Note: In brackets are the standard errors of the coefficients. The asterisks represent significance at $1 \%\left({ }^{* * *}\right)$ confidence levels.

We estimated the cross-sectional fixed effects models with the option, Cross-section weights, for using a feasible GLS specification, assuming the cross-sectional heteroscedasticity. When using the GLS specification and the cross-sectional SUR to estimate, we agree to correct for both the heteroscedasticity and the contemporaneous correlations between the cross sections. Using the estimation with the generalized least squares (GLS) method, and the optional cross-sectional SUR of the cross-sectional fixed effects model, we get consistent and optimal estimators.

The cross-sectional heteroscedasticity is solved by cross-section weights, but not by the cross-dependence of the residuals. When there is the suspicion of the existence of contemporaneous correlations between cross sections, GLS with SUR weights can be applied. We eliminate the heteroscedasticity, and we have no cross-sectional dependence 
in the residuals. When comparing only the $\mathrm{R}^{2}$ of the fixed effects models, we see that by using GLS estimation with cross-sectional SUR, we get better values for explaining the ROA variation. The same type of panel data model was used: a cross-sectional fixed effects model, with GLS cross-section weights, in order to solve the heteroscedasticity.

The panel models all have coefficients that are significant, at less than a $1 \%$ significance level. When considering only the short panels (the 2012 panel is long), we notice that the models become better when the subperiods before the demergers are longer. The longer the subperiod before a demerger, the better the explanation of the ROA variation by the models, as their coefficients of determination show in Table 5.

The coefficients of the ROE and the PR_MG show positive influences over the ROA, and the sign of the coefficient of the INDBT_DG variable is negative, as we expected. The subperiods before the demergers are longer then the influence of the ROEs becoming greater, except for the 2012 panel. Moreover, the influence of the INDBT_DG on the ROA variation is better, with a lower negative influence on the ROA.

The influences of the explanatory variables in the post-division subperiod are highlighted by the coefficients of the dummy variables corresponding to each panel, and are multiplied with them. In this way, the influence of each variable on the ROA is amplified or diminished with these terms in the post-demerger subperiod. These models describe both situations: before and after the division, when DUM $=0$ and when DUM $=1$, respectively.

For the 2012 panel, we see that the interactions of DUM * ROE and DUM * PR_MG negatively influenced the ROAs in the years after the divisions, leading to decreases in the influences of these variables on the ROAs. In the post-division subperiod, each percentage point of ROE growth led to an increase in the ROA, averaging 2.8 percentage points (pp), and an increase of 1 pp in the PR_MG led to an average positive influence of 2.3 p.p. on the ROA. This is not the case for the INDBT_DG variable, whose influence on the ROAs throughout the period was the same negative value of $-13.8 \mathrm{pp}$ for each percentage point increase of the INDBT_DG. Thus, in each year of the second subperiod, the influences of the ROEs and the PR_MGs on the ROAs were lower than before the divisions; the approximate coefficients of these variables in the post-demerger subperiod model can be seen in Table 6.

Table 6. The cross-sectional FE models of subperiods, before and after demergers, for each panel.

\begin{tabular}{|c|c|c|c|c|c|c|c|c|}
\hline \multirow{2}{*}{$\begin{array}{l}\text { Cross-Sectional FE } \\
\text { GLS-Cross- } \\
\text { Section Weights }\end{array}$} & \multicolumn{2}{|c|}{2012 Panel } & \multicolumn{2}{|c|}{2013 Panel } & \multicolumn{2}{|c|}{2014 Panel } & \multicolumn{2}{|c|}{2015 Panel } \\
\hline & 2005-2012 & 2013-2019 & 2005-2013 & 2014-2019 & 2005-2014 & 2015-2019 & 2005-2015 & 2016-2019 \\
\hline $\begin{array}{l}\mathrm{ROA}- \\
\text { dependent variable }\end{array}$ & $\mathrm{a}_{\mathrm{i}}^{* * *}$ & $a_{i}^{* * *}$ & $a_{i}^{* * *}$ & $a_{i}^{* *}$ & $a_{i}^{* * *}$ & $a_{i}^{* * *}$ & $\mathrm{a}_{\mathrm{i}}^{* * *}$ & $\mathrm{a}_{\mathrm{i}}^{* * *}$ \\
\hline $\mathrm{C}$ & $\begin{array}{c}0.046 \\
(0.007)\end{array}$ & $\begin{array}{c}0.160 \\
(0.025)\end{array}$ & $\begin{array}{c}0.134 \\
(0.016)\end{array}$ & $\begin{array}{l}0.207 * * * \\
(0.020)\end{array}$ & $\begin{array}{c}0.073 \\
(0.012)\end{array}$ & $\begin{array}{c}0.095 \\
(0.003)\end{array}$ & $\begin{array}{c}0.034 \\
(0.002)\end{array}$ & $\begin{array}{c}0.051 \\
(0.005)\end{array}$ \\
\hline ROE & $\begin{array}{c}0.150 \\
(0.018)\end{array}$ & $\begin{array}{c}0.032 \\
(0.006)\end{array}$ & $\begin{array}{c}0.025 \\
(0.004)\end{array}$ & $\begin{array}{l}0.018 * * \\
(0.008)\end{array}$ & $\begin{array}{c}0.149 \\
(0.013)\end{array}$ & $\begin{array}{c}0.005 \\
(0.001)\end{array}$ & $\begin{array}{c}0.235 \\
(0.012)\end{array}$ & $\begin{array}{c}0.460 \\
(0.014)\end{array}$ \\
\hline INDBT_DG & $\begin{array}{l}-0.045 \\
(0.008)\end{array}$ & $\begin{array}{l}-0.222 \\
(0.032)\end{array}$ & $\begin{array}{l}-0.132 \\
(0.027)\end{array}$ & $\begin{array}{c}-0.282 * * * \\
(0.040)\end{array}$ & $\begin{array}{l}-0.069 \\
(0.018)\end{array}$ & - & $\begin{array}{l}-0.015 \\
(0.005)\end{array}$ & $\begin{array}{l}-0.107 \\
(0.010)\end{array}$ \\
\hline PR_MG & $\begin{array}{c}0.353 \\
(0.032)\end{array}$ & $\begin{array}{c}0.020 \\
(0.003)\end{array}$ & $\begin{array}{c}0.030 \\
(0.006)\end{array}$ & $\begin{array}{l}0.131^{* * *} \\
(0.022)\end{array}$ & $\begin{array}{c}0.318 \\
(0.027)\end{array}$ & $\begin{array}{c}0.192 \\
(0.011)\end{array}$ & $\begin{array}{c}0.346 \\
(0.023)\end{array}$ & $\begin{array}{c}0.063 \\
(0.013)\end{array}$ \\
\hline $\mathrm{R}^{2}$ & $96.5 \%$ & $83.5 \%$ & $65.7 \%$ & $80.0 \%$ & $89.9 \%$ & $92.0 \%$ & $93.2 \%$ & $98.8 \%$ \\
\hline
\end{tabular}

Note: In brackets are the standard errors of the coefficients. The asterisks represent significances at the $5 \%\left({ }^{* *}\right)$, and $1 \%(* * *)$ confidence levels.

For the 2013 panel, we see that the ROEs have the same influence on the ROAs in both subperiods. The annual influence of the ROEs on the ROAs is, on average, 2.5 p.p. throughout the period. In each year of the second subperiod, the negative influence of the INDBT_DG is diminished, on average, to -19.4 pp, and the influence of the PR_MG is, on average, $8.8 \mathrm{pp}$ for each percentage point of its growth, when the other factors are kept constant. Thus, in the post-demerger subperiod, the INDBT_DGs and PR_MGs have better influences on the ROAs than before the demergers. 
For the 2014 panel, we see that, after the demerger, the ROEs and PR_MGs diminish their positive influence on the ROAs, and the INDBT_DGs reduce their negative influence on the ROAs. These effects can also be seen in Table 6 , in the model coefficients for the post-demerger subperiod that describe the approximate effects of the significant variables on the ROAs of $0.5 \mathrm{pp}$ for a one percentage point increase of the ROE, and $19.8 \mathrm{pp}$ for a one percentage point increase of the PR_MG.

The 2015 panel has the shortest period, of only four years, after the division; we conclude that the ROEs and PR_MGs still have high annual influences on the ROAs, compared to previous panels. For the 2015 panel, profit management is still very importantthe ROE influence is increasing, but the pressure of the degree of indebtedness is slightly diminished in the ROA variation, compared to the previous panels. We conclude that the size of the subperiod is very important for the recovery after splitting.

When the period after the demerger is larger, as in the previous panels, the influence of the ROE and PR_MG becomes lower. The newly changed company is on its own on the markets, and it is forced to act by increasing the indebtedness degree in order to continue to develop itself. After a demerger, the management staff becomes more experienced in time to handle the indebtedness degree, being preoccupied with increasing the sales turnover and the profit.

These panel models, with dummy variables of the entire period, emphasize the behaviors of the variables in the ROA variation, and the conclusions support the results of the econometric models on the corresponding subperiods for each panel.

\subsubsection{Econometric Models of the Panels on the Corresponding Subperiods before and after Demergers}

When applying the cross-sectional fixed effects model for each subperiod, we found that the number of observations for the cross-sectional SUR estimation was insufficient. In this case, we used GLS with cross-section weights, and we found that the $\mathrm{H}_{0}$ of the non-cross-sectional dependence in the residuals can be accepted for both subperiods. We built the models for each subperiod before and after the demergers, and each one was specific to each panel. The determination coefficients, $R^{2}$, show high levels, higher than for the cross-sectional FE model with GLS with cross-section weights for the whole period.

Table 6 contains the estimated cross-sectional fixed effects models for all the analyzed panels, before and after the demergers. All the coefficients of the cross-sectional fixed effects models are significant at less than a $1 \%$ significance level, having the expected signs: positive for the ROE and PR_MG, and negative for the INDBT_DG.

Before the demergers, except for the 2013 panel data, the coefficients of the PR_MGs are quite similar, showing approximately the same influence on the ROA variation, of around 30-35 pp for an increase of one percentage point of the PR_MG, keeping the other explanatory variables constant. The determination coefficients, $R^{2}$, for these models are higher than $92 \%$. For before the demerger subperiod, the 2013 panel had a determination coefficient, $R^{2}$, of about $66 \%$, and it was characterized by a higher negative influence of the indebtedness degree (INDBT_DG) over the ROA, which reduced the influences of the PR_MG and ROE, compared with the other three panels, in Table 6.

After the demergers, the influence of the ROEs on the ROA variation decreased for the first three panels, but doubled for the 2015 panel, compared to the previous subperiod. For all the panels, the negative influence of the INDBT_DGs on the ROAs after the demergers were higher than before. For almost all the panels, the influence of the PR_MGs on the ROAs diminished after the demergers. In all the models in Table 6, we can see that the PR_MGs had a greater influence on the ROAs than the ROEs, especially in the first subperiod, except for the second subperiod of the 2015 panel. The cross-sectional FE models of the subperiods have determination coefficients $\left(R^{2}\right)$ higher than $90 \%$, proving themselves very good models.

The econometric models of the two subperiods offer better results than the consideration of the FE model for the whole period from 2005-2019. The theoretical ROAs for each 
panel were obtained by combining the two subperiod models into a single series, called the

"ROA_TH_SUBPERIODS", as seen in Figure 3.
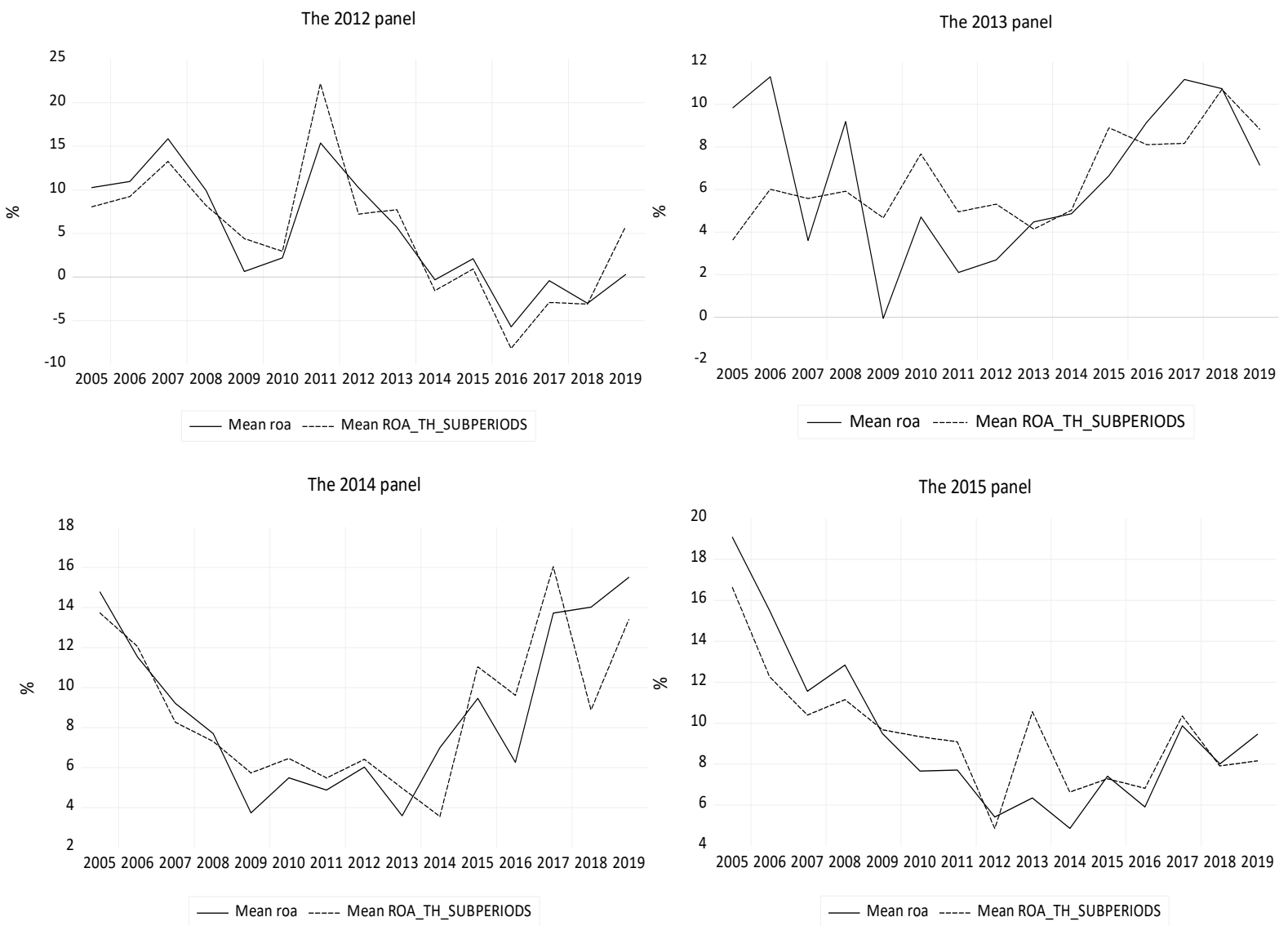

Figure 3. Average ROAs and theoretical average ROAs based on the subperiod models of the panels.

The evolution of the average ROA values of each panel, and of the theoretical average ROA values, can be seen in Figure 3, for each panel. The cross-sectional fixed effects are annulled at the panel level.

For the 2012 panel, the ROA values decreased after the demergers in 2012, but an upward trend is evident from 2017 to the last year, 2019. For the 2013, 2014, and 2015 panels, we see in Figure 3 a better evolution of the average ROAs in the second subperiod than in the first subperiod. We conclude that the companies recovered after the demergers, and the econometric models prove this. We can say that the $\mathrm{H} 1$ hypothesis has been proven by the validity of the econometric models used for each panel.

We conclude that, after the demergers, the interest of investors decreased, and the ROE had less influence on the ROA. The positions of the companies on the markets are weakening, and this fact is proven by the diminishing influence of the PR_MG on the ROA variation. Meanwhile, the negative influence of the INDBT_DG is increasing, which means that the debt management is putting on more pressure than before the demergers, in the new economic conditions.

The cross-sectional fixed effects models reveal the difficulties for management in creating revenue, reinvesting profit, managing debt, and facing markets, immediately after the demergers.

\subsection{Analyzing the Economic Statuses of Romanian Companies, before and after the Demergers}

We compare the ROAs in the early common subperiod, 2005-2011, before all the demergers, in Table 7 , and in the subsequent subperiod of all the demergers, the recent common subperiod, 2016-2019, in Table 8. 
Table 7. ROA statistics of panels and for all demerged companies in the subperiod, 2005-2011.

\begin{tabular}{|c|c|c|c|c|c|}
\hline \multirow{2}{*}{ ROA } & \multicolumn{4}{|c|}{ 2005-2011 } & \multirow{2}{*}{$\begin{array}{l}\text { 2005-2011 } \\
\text { All Panels }\end{array}$} \\
\hline & 2012 Panel & 2013 Panel & 2014 Panel & 2015 Panel & \\
\hline Mean & $9.3 \%$ & $5.8 \%$ & $8.2 \%$ & $12.0 \%$ & $9.0 \%$ \\
\hline Median & $4.2 \%$ & $3.3 \%$ & $3.4 \%$ & $5.5 \%$ & $4.0 \%$ \\
\hline Maximum & $173.0 \%$ & $84.8 \%$ & $49.4 \%$ & $188.8 \%$ & $188.8 \%$ \\
\hline Minimum & $-76.3 \%$ & $-62.7 \%$ & $-11.9 \%$ & $-10.0 \%$ & $-76.3 \%$ \\
\hline Std. Dev. & $28.1 \%$ & $21.9 \%$ & $12.1 \%$ & $21.1 \%$ & $20.8 \%$ \\
\hline Observations & 56 & 147 & 112 & 175 & 490 \\
\hline No. of Firms $(n)$ & 8 & 21 & 16 & 25 & 70 \\
\hline Limit error $(p=95 \%)$ & $4.3 \%$ & $2.2 \%$ & $1.1 \%$ & $2.0 \%$ & $1.1 \%$ \\
\hline 95\% CI Lower & $5.0 \%$ & $3.7 \%$ & $7.1 \%$ & $10.0 \%$ & $7.9 \%$ \\
\hline 95\% CI Upper & $13.6 \%$ & $8.0 \%$ & $9.3 \%$ & $13.9 \%$ & $10.0 \%$ \\
\hline
\end{tabular}

Table 8. ROA statistics of panels and for all demerged companies, in the subperiod, 2016-2019.

\begin{tabular}{lccccc}
\hline \multirow{2}{*}{ ROA } & \multicolumn{4}{c}{$\mathbf{2 0 1 6 - 2 0 1 9}$} & 2016-2019 \\
\cline { 2 - 6 } & $\mathbf{2 0 1 2}$ Panel & 2013 Panel & 2014 Panel & 2015 Panel & All Panels \\
\hline Mean & $-2.2 \%$ & $9.6 \%$ & $12.4 \%$ & $8.3 \%$ & $8.4 \%$ \\
\hline Median & $1.7 \%$ & $4.4 \%$ & $5.3 \%$ & $3.9 \%$ & $3.9 \%$ \\
\hline Maximum & $87.6 \%$ & $86.0 \%$ & $97.1 \%$ & $70.1 \%$ & $97.1 \%$ \\
\hline Minimum & $-113.8 \%$ & $-56.4 \%$ & $-49.8 \%$ & $-21.0 \%$ & $-113.8 \%$ \\
\hline Std. Dev. & $29.6 \%$ & $20.5 \%$ & $23.4 \%$ & $15.1 \%$ & $21.1 \%$ \\
\hline Observations & 32 & 84 & 64 & 100 & 280 \\
\hline No. of Firms $(n)$ & 8 & 21 & 16 & 25 & 70 \\
\hline Limit error $(p=95 \%)$ & $6.0 \%$ & $2.7 \%$ & $2.8 \%$ & $1.9 \%$ & $1.5 \%$ \\
\hline $95 \%$ CI Lower & $-8.2 \%$ & $6.9 \%$ & $9.6 \%$ & $6.5 \%$ & $7.0 \%$ \\
\hline $95 \%$ CI Upper & $3.8 \%$ & $12.2 \%$ & $15.2 \%$ & $10.2 \%$ & $9.9 \%$ \\
\hline
\end{tabular}

Table 7 contains the limit errors, with a 95\% probability, for the average annual ROAs for each demerger year, in the subperiod from 2005-2011, as well as the corresponding ROA confidence intervals, with a probability of $95 \%$, for all the Romanian companies that demerged. The economic crisis of 2008 is included in the analyzed subperiod of 2005-2011. The annual average value of the ROAs for all the sampled companies in the panels was around $9 \%$ (last column of Table 7). We can see that the average ROAs of the panels were between more than $5 \%$ in the 2013 panel and $12 \%$ in the 2015 panel, in Table 7.

When we consider all the companies that demerged in the period from 2012-2015, we notice that their average annual ROAs before the demerger actions were in the range of $8 \%$ to $10 \%$, with a probability of $95 \%$.

For the subperiod of 2016-2019, the annual average value of the ROAs for all the companies in the panels was $8.4 \%$ (last column of Table 8 ).

With the exception of the 2012 panel, the average ROAs of the panels were between $8.3 \%$ in the 2015 panel and $12.4 \%$ in the 2014 panel. Table 8 also contains the limit errors of each panel for the 2016-2019 subperiod, as well as the ROA confidence intervals, with a probability of $95 \%$. The panel confidence intervals are higher after the demergers than before the demergers, especially for the 2013 and 2014 panels, in Tables 7 and 8. This conclusion supports the $\mathrm{H} 2$ hypothesis. For the 2012 panel, we can see that three years after the demergers, the companies were still making difficult recoveries. All of the companies 
that demerged in 2012, in the subsequent subperiod of 2016-2019, had average ROAs in the range of $-8.2 \%$ and $3.8 \%$. However, the 2012 panel is a long panel, so we avoid drawing conclusions on the basis of it.

We conclude that, after the demergers, during 2016-2019, all the Romanian companies had ROAs between $7 \%$ and $10 \%$, with a probability of $95 \%$.

For the most part, all of the demerged Romanian companies faced the same situation in 2016-2019, as in the subperiod prior to the division, from 2005-2011. Looking to these confidence intervals, we appreciate that recoveries were made by all of the Romanian demerged companies. These results support the $\mathrm{H} 2$ hypothesis.

\subsection{Modeling the Economic Statuses of Companies before and after Demergers}

Fixed effects models were used to compare the economic performances in the period from 2005-2011, the early common period, before the demergers for all panels, and in 2016-2019, their last common period, after the demergers.

For each panel, we can see the decreasing positive influences of the ROEs and the PR_MGs, and the increasing negative influence of the INDBT_DGs on the ROAs, after the demergers, in Table 9.

Table 9. The cross-sectional FE models for the subperiods of 2005-2011 and 2016-2019, for each panel and for all companies.

\begin{tabular}{|c|c|c|c|c|c|c|c|c|c|c|}
\hline \multirow{2}{*}{$\begin{array}{l}\text { Cross-Section FE } \\
\text { GLS-Cross- } \\
\text { Section Weights }\end{array}$} & \multicolumn{2}{|c|}{2012 Panel } & \multicolumn{2}{|c|}{2013 Panel } & \multicolumn{2}{|c|}{2014 Panel } & \multicolumn{2}{|c|}{2015 Panel } & \multicolumn{2}{|c|}{ All Panels } \\
\hline & 2005-2011 & 2016-2019 & 2005-2011 & 2016-2019 & 2005-2011 & 2016-2019 & 2005-2011 & 2016-2019 & 2005-2011 & 2016-2019 \\
\hline $\begin{array}{l}\text { ROA- } \\
\text { dependent variable }\end{array}$ & $a_{i}^{* * *}$ & $a_{i}^{* * *}$ & $a_{i}^{* * *}$ & $\mathrm{a}_{\mathrm{i}}^{* * *}$ & $a_{i}^{* * *}$ & $a_{i}^{* * *}$ & $a_{i}^{* * *}$ & $\mathrm{a}_{\mathrm{i}}^{* * *}$ & $\mathrm{a}_{\mathrm{i}}^{* * *}$ & $\mathrm{a}_{\mathrm{i}}$ \\
\hline C & $\begin{array}{c}0.046 \\
(0.008)\end{array}$ & $\begin{array}{c}0.287 \\
(0.054) \\
\end{array}$ & $\begin{array}{c}0.147 \\
(0.022) \\
\end{array}$ & $\begin{array}{c}0.203 \\
(0.019) \\
\end{array}$ & $\begin{array}{c}0.173 \\
(0.021) \\
\end{array}$ & $\begin{array}{c}0.100 \\
(0.004) \\
\end{array}$ & $\begin{array}{c}0.050 \\
(0.005) \\
\end{array}$ & $\begin{array}{c}0.051 \\
(0.005) \\
\end{array}$ & $\begin{array}{c}0.153 \\
(0.008) \\
\end{array}$ & $\begin{array}{c}0.094^{* * *} \\
(0.006)\end{array}$ \\
\hline ROE & $\begin{array}{c}0.141 \\
(0.020)\end{array}$ & $\begin{array}{c}0.028 \\
(0.004)\end{array}$ & $\begin{array}{c}0.046 \\
(0.011)\end{array}$ & $\begin{array}{c}0.076 \\
(0.019)\end{array}$ & $\begin{array}{c}0.190 \\
(0.012)\end{array}$ & $\begin{array}{c}0.005 \\
(0.001)\end{array}$ & $\begin{array}{c}0.330 \\
(0.015)\end{array}$ & $\begin{array}{c}0.460 \\
(0.014)\end{array}$ & $\begin{array}{c}0.103 \\
(0.006)\end{array}$ & $\begin{array}{l}0.007^{* * *} \\
(0.002)\end{array}$ \\
\hline INDBT_DG & $\begin{array}{l}-0.047 \\
(0.009)\end{array}$ & $\begin{array}{l}-0.371 \\
(0.064)\end{array}$ & $\begin{array}{l}-0.161 \\
(0.039)\end{array}$ & $\begin{array}{l}-0.319 \\
(0.038)\end{array}$ & $\begin{array}{l}-0.236 \\
(0.030)\end{array}$ & - & $\begin{array}{l}-0.061 \\
(0.010)\end{array}$ & $\begin{array}{l}-0.107 \\
(0.010)\end{array}$ & $\begin{array}{l}-0.148 \\
(0.013)\end{array}$ & $\begin{array}{l}-0.019 * \\
(0.012)\end{array}$ \\
\hline PR_MG & $\begin{array}{c}0.350 \\
(0.032)\end{array}$ & $\begin{array}{c}0.019 \\
(0.004)\end{array}$ & $\begin{array}{c}0.024 \\
(0.007)\end{array}$ & $\begin{array}{c}0.242 \\
(0.045)\end{array}$ & $\begin{array}{c}0.307 \\
(0.032)\end{array}$ & $\begin{array}{c}0.191 \\
(0.010)\end{array}$ & $\begin{array}{c}0.281 \\
(0.029)\end{array}$ & $\begin{array}{c}0.063 \\
(0.013)\end{array}$ & $\begin{array}{c}0.045 \\
(0.008)\end{array}$ & $\begin{array}{l}0.036^{* * *} \\
(0.002)\end{array}$ \\
\hline $\mathrm{R}^{2}$ & $96.5 \%$ & $92.8 \%$ & $66.7 \%$ & $93.2 \%$ & $93.2 \%$ & $95.5 \%$ & $95.4 \%$ & $98.8 \%$ & $79.5 \%$ & $89.7 \%$ \\
\hline
\end{tabular}

Note: In brackets are the standard errors of the coefficients. The asterisks represent significances at the $10 \%(*)$ and $1 \%(* *)$ confidence levels.

For the 2015 panel, the time interval after the post-demergers is still short, and the influences of the ROEs and the INDBT_DGs on the ROAs are even greater than in first subperiod.

Regardless of the panel, with a probability of $90 \%(*, 10 \% p$-value for the coefficient of the variable, the INDBT_DG), we can accept the results described by the cross-sectional FE model of the companies in all the panels, for 2016-2019 (the last column of Table 9). For this model, we can see that the influences of all the factors decrease after the demergers. The indebtedness degree has a lower negative influence in the second subperiod than in the first one. Moreover, the ROEs and PR_MGs have lower positive influences on the ROAs in the second subperiod.

We see that almost all of the econometric models with cross-sectional FE presented in Table 9 have significant coefficients, with a probability of $99 \%$. The high values of the coefficients of determination, $\mathrm{R}^{2}$, show that the models explain, in very large proportions, the variation in the ROAs determined by the influence factors: the ROE, the INDBT_DG, and the PR_MG.

Figure 4 shows the evolution of the average ROAs of all the companies, during the two analyzed subperiods; the ROAF is the forecasted series calculated with the corresponding FE models of the subperiods. 

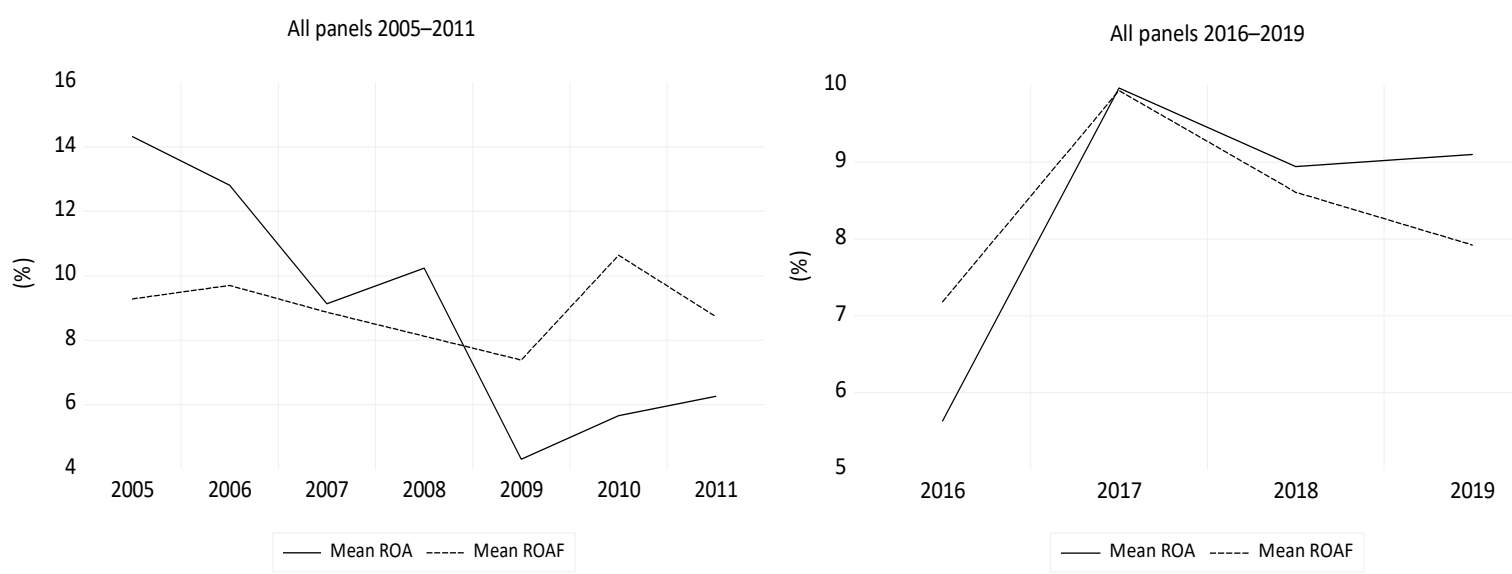

Figure 4. Average ROAs and theoretical average ROAs (ROAFs) in the two stable subperiods, for all companies in the panels.

We can identify the estimated ROA confidence intervals for all the demerged companies in Tables 7 and 8 if we look at the lower and upper theoretical ROA values (ROAFs), which are based on the econometric models in Figure 4, for both of the analyzed subperiods.

The conclusions of the econometric analysis are in line with the results of the comparison of the economic performances of the two stable subperiods, before and after all the demergers, presented in Section 4.3. The results of the econometric approach are consistent with the results of the statistical analyses of the samples. Moreover, the econometric models reveal the significant influences of the factors considered in the ROA variation in the established subperiods, and they prove that the $\mathrm{H} 2$ hypothesis is true.

The recoveries after the demergers were completed, as can be seen in Figure 4, and there were no dramatic changes after the demergers.

\section{Conclusions}

The demerger phenomenon seems to be underestimated in the economic literature, although, in the real economic world, it can play a sanitizing and even a safeguarding role for entities in need. As they become larger through repetitive mergers, entities gain in size but loose in flexibility, and, thus, crises and abrupt sectoral changes can affect them to the point of menacing their very existence.

\subsection{Scientific Contributions to the Literature}

The phenomenon of demergers is still in its infancy in the emerging Romanian economy. Our paper is one of the first to explain the phenomenon of demergers in Romania and is the first to be based on an econometric approach, showing causality, and quantifying the influences and outcomes.

The demerger solution seems to be the most natural, in the absence of the synergies that determined the merger initially, but whether this is also efficient in terms of the financial indicators post vs. ante scission in a certain economic environment, was defined in our main hypotheses. In order to achieve this objective, we have monitored data on 70 Romanian companies that demerged during the 2012-2015 period, and we have organized them into four data panels.

The paper assesses the financial sustainability of the demerged companies, as well as their ability to continue their long-term business after the demerger process. The added value of this study is provided by the methodology used, namely, econometric models, which were meant to highlight the power of the companies to recover after the division process.

The connection between the demergers and the sustainable development of companies creates originality and adds value to our study. 
Our research differs from other studies by the methodology used to characterize the phenomenon of the demerger. On the basis of econometric models, the study examines the implications of demergers on the sustainable development of economic entities. The paper completes and improves the literature on the restructuring of economic entities.

Creating distinct entities, specialized in a specific sector of activity, with separated budgets of revenues and expenditures, can contribute to the better efficiency and profitability of each entity.

Demergers can be seen as a tool that generates value for companies in general, as well as for managers and other stakeholders. We demonstrated this by applying the econometric models and by the results obtained in this study. The value created by the demerger process may result from the separation of the competitive activities from the less competitive ones, separating the risks associated with each line of activity, separating investment objectives, etc.

Managers, investors, financial analysts, and other stakeholders may be interested in the financial evolution of companies after the demerger process for their long-term growth and development potentials.

Each panel is a randomly chosen sample of companies, consisting of the firms that had publicly declared their financial indicators and that had proceeded to demerger projects. The firms are evolving in the same regulatory economic environment. In this respect, the results of our study can be considered reliable because the stochastic character of the sampling was ensured, both for each panel, and for the samples formed by the companies of the four panels.

The ROA statistical analysis of each panel in each subperiod, before and after the demergers, led us to conclude that the Romanian companies were fully recovered after at least five years.

We estimated the size of the demerger phenomenon and we found the amplitude of the financial performances of Romanian companies before their division decisions.

We assessed the confidence intervals of the average ROAs for all Romanian companies, even before their demerger decisions, on the basis of the analysis of the 2005-2011 subperiod. We found that all of the Romanian companies had average ROAs in the range of between $8 \%$ and $10 \%$, with a probability of $95 \%$, before the demerger decision.

After all the demerger actions in the period of 2012-2015, we estimated that all Romanian companies had ROAs between $7 \%$ and $10 \%$, with a probability of $95 \%$, on the basis of the analysis from the 2016-2019 subperiod.

Our research is also noteworthy because of the proposed research methodology, which characterizes the phenomenon of demergers.

The panels comprise company data for the period of 2005-2019, from various industries. The aspects of the diverse activity domains and the different sizes of the companies are encompassed in the fixed effects of the panel data models. The cross-sectional fixed effects models considered the characteristics of each company and industry and maintained them over time.

The variables that influence the ROA variation, taken into account by the proposed models, in almost all cases had significant coefficients at a significance level of less than $1 \%$. The conclusion is that the cross-sectional fixed effects models proposed for the panels in certain subperiods highlight the fact that the determinants of the sustainable development of companies after demergers are mainly found within them. The ability to manage revenue creation depends on the capability of attracting resources through investments (ROE), debts (INDBT_DG), and market positions (PR_MG).

All our econometric models show positive coefficients for the ROE and PR_MG variables, and negative coefficients of the INDBT_DG variable, as we expected. All models have high levels of determination coefficients, which explains the high proportions of ROA variation, depending on the chosen influencing factors.

We have also used the fixed effects models to compare the ROAs in the early common period, before the demergers, for all panels in 2005-2011 and in 2016-2019, the last common 
period after all the demergers. For each panel, after the demergers, the ROEs and PR_MGs had decreasing positive influences, while the INDBT_DGs presented an increasing negative influence over the ROAs.

The results of each panel led us conclude that the demerger decisions were good in ensuring the sustainability of the companies' activities and helped them to continue their economic existences. We see that, for each panel, the ROA evolution has a gradual upward trend, proven and supported by the identified econometric models.

The results confirm the recoveries of the demerged companies, although the ROA amplitude does not pick up in a steep way, but, rather, ensures the survival and continuity of the business activities.

The data panel modeling describes the demerger phenomenon in Romania, starting in 2012 and continuing until 2015. The evolution of the financial indicators, before and after the years of the demergers, defines the consequences and the efforts for better economic performances, through the significant influences of the considered factors.

We also analyzed and modeled the average ROAs for all 70 companies in the four panels, during two stable subperiods, one before the first demerger, and the other after the last demerger. We extended the results of the panels at the statistical level of the population, for all 107 Romanian companies that were demerged in the period from 2012-2015, with a probability of $95 \%$.

We applied statistical and econometric analyses on the ROAs and found quite similar confidence intervals, of $7-8 \%$ and $10 \%$, in the ante- and post-demerger subperiods, respectively. We are able to attest that the Romanian companies fully recovered after the demergers.

The reasons for demerger decisions are different, and as the dynamics of economic relations determine them, they generally lead to a healthier development in their immediate economic environment and at the national scale. Their sanitizing role is confirmed by the outcomes of our research, which shows the positive trends of the considered performance indicators, and, thus, the recoveries of the affected entities.

\subsection{The Limits of the Study}

Some limits of this research may take into account the indicators used to describe the economic performances of the companies.

A limitation of the ROA is that it can vary substantially from one industry to another. The ROAs were compared with their previous values, considering their evolution for each company. At the panel data level, the average values of the ROAs and the theoretical average ROAs were compared over time. The analysis does not compare companies from one industry to others in the same industry, nor the industries between them.

The ROE encompasses the value of a company to investors, even if is not listed on the financial markets.

Other limits of the research may relate to the lack of an economic context within which to consider our analyses. We refer strictly to the phenomenon of demergers, without looking at the state of the economy.

\subsection{Further Directions of the Research}

Further research may envisage similar analyses to establish specific ROA levels for the demerged companies per activity sectors. Future research may also consider how the phenomenon of demergers influences the dynamics of the economy.

In conclusion, we find it interesting to assess whether the defined economic environments have economic profiles specific to the reorganization of companies through mergers, demergers, and acquisitions in different stages of their development.

Identifying the trends of a certain type of entity reorganization may reveal the global tendencies of economic dynamics and may allow for a comparison of the different consequences of these actions. 
Another further direction of research is to compare the financial performance and gaps of Romanian companies after demergers with other post-transition countries, as well as between companies from different European countries.

The use of the statistical and econometric analyses can reveal whether the reorganizations adopted by companies in an economy are objective or not. The efficiency of such actions is also to be assessed, per sectors, per economic cycles, and in relation to the sizes of the demerged entities.

The current analysis establishes that the demergers of Romanian companies in the period from 2012-2015 led to better economic performances, individually and overall; moreover, it was the only way to survive: by obtaining and efficiently utilizing resources, and by facing the resilience of the economic forces of market competition, in the context of the accession to the European Union, and after the economic crisis in late 2008.

Author Contributions: All the authors contributed equally throughout the entire process of completing the research. C.D. (Constantin Duguleana) and L.D. conceived the study and were responsible for the methodology, structure design, and development of the data analysis. C.M.B. and C.D. (Cristina Drumea) were responsible for the data collection, validation, supervision, review, and project administration. C.D. (Constantin Duguleana) and L.D. wrote the first draft of the article, reviewed and interpreted the results, and they are responsible for the data interpretation. All authors have read and agreed to the published version of the manuscript.

Funding: This research received no external funding.

Institutional Review Board Statement: Not applicable.

Data Availability Statement: The data presented in this study are available upon request from the corresponding author.

Conflicts of Interest: The authors declare no conflict of interest.

\section{References}

1. Abou Elseoud, E.M.S.; Yassin, M.; Asad, M.A.M. Using a panel data approach to determining the key factors of Islamic banks' profitability in Bahrain. Cogent Bus. Manag. 2020, 7, 1-16. [CrossRef]

2. Bao, H. Evaluation of Pre and Post Demerger-Merger Performance: Using ABN AMRO Bank as an Example. Int. J. Econ. Financ. 2017, 9, 196-204. [CrossRef]

3. Pazarskis, M.; Drogalas, G.; Koutoupis, A. Mergers and accounting performance: Some evidence from Greece during the economic crisis. Account. Manag. Inf. Syst. 2018, 17, 31-45. [CrossRef]

4. Pazarskis, M.; Vogiatzoglou, M.; Koutoupis, A.; Drogalas, G. Corporate Mergers and Accounting Performance during a Period of Economic Crisis: Evidence from Greece. J. Bus. Econ. Manag. 2021, 22, 577-595. [CrossRef]

5. Pantelidis, P.; Pazarskis, M.; Drogalas, G.; Zezou, S. Managerial decisions and accounting performance following mergers in Greece. Invest. Manag. Financ. Innov. 2018, 15, 263-276. [CrossRef]

6. Daddikar, P.; Shaikh, A.R. Impact of mergers \& acquisitions on surviving firm's financial performance: A study of Jet Airways Ltd. Pac. Bus. Rev. Int. 2014, 6, 45-51.

7. Nuray, I. Analysis of the Factors that Determine the Profitability of the Deposit Banks in Turkey. J. Appl. Financ. Bank. 2015, 5, 175-186.

8. Polemis, D.; Karlis, T. Measuring post-merger and acquisition performance of corporations in the Maritime transport sector. SPOUDAI J. Econ. Bus. 2016, 66, 83-93.

9. Khudadad, S.; Tahir, M.; Ghulam, J. The Comparative Financial Performance of Outsourcing and Vertically Integrated Corporations. East Asian J. Bus. Manag. 2018, 8, 23-31. [CrossRef]

10. Singhal, S. Does Break up Lead to Break down? Effect of Demerger on financial Firm Performance: The cases of Demerger. Int. J. Manag. IT Eng. 2019, 9, 322-333.

11. Aggarwal, M.; Singh, S. Effect of Merger on Financial Performance: A Case Study of Kingfisher Airlines. In Proceedings of the XVI International Conference on "Governance: Changing Paradigms", Delhi, India, 3-4 January 2015; pp. $399-413$.

12. Panda, B.; Rao, P.H. Corporate restructuring: Demerging impact. SCMS J. Indian Manag. 2012, 9, 80-87.

13. Allen, J.W. Private Information and Spin-Off Performance. J. Bus. 2001, 74, 281-306. [CrossRef]

14. Fici, L.; Malyzhenkov, P.V.; Piccarozzi, M.; Meleshina, E.S. Spin-off design as an organizational practice: A methodological approach. Бизнес-информатика 2016, 3, 7-14. [CrossRef]

15. Asghari, R.; Kokemper, B. The impact of entrepreneurship governance and institutional frameworks on knowledge-based spin-offs. In Technology Entrepreneurship; Springer: Cham, Switzerland, 2018; pp. 225-240. 
16. Vekic, A.; Djakovic, V.; Borocki, J.; Sroka, W.; Popp, J.; Olàh, J. The importance of academic new ventures for sustainable regional development. Amfiteatru Econ. 2020, 22, 533-550. [CrossRef]

17. Kirchmaier, T. The Performance Effects of European Demergers. Discussion Papers No. 566. 2003. Available online: https: / / cep.lse.ac.uk/_NEW/PUBLICATIONS/abstract.asp?index=1945 (accessed on 6 November 2021).

18. Mason, E.S. The current status of the monopoly problem in the United States. Harv. Law Rev. 1948, 62, 1265. [CrossRef]

19. Bain, J.S. Barriers to New Competition. Their Character and Consequences in Manufacturing Industries; Harvard University Press: Cambridge, MA, USA, 1956; pp. 182-204.

20. Lopez, E.J. New anti-merger theories: A critique. Cato J. 2000, 20, 359.

21. Lucas Robert, E. Econometric Policy Evaluation: A Critique. Carnegie-Rochester Conf. Ser. Public Policy 1976, 1, 19-46. [CrossRef]

22. McChesney, F.S. Be true to your school: Chicago's contradictory views of antitrust and regulation. Cato J. 1991, 10, 775-798.

23. Rapp, R.T. The misapplication of the innovation market approach to merger analysis. Antitrust LJ 1995, 64, 19.

24. Spence, M. Contestable Markets and the theory of Industry Structure: A review article. J. Econ. Lit. 1983, 21, 981-990.

25. Stigler, G.S. The Economic Effects of Antitrust Laws. J. Law Econ. 1966, 9, 225-258. [CrossRef]

26. Kotran, S.; Katz, M.; Khan, S. Spin-offs. Pract. Law J. 2010, 36-47.

27. Habib, M.A.; Johnsen, D.B.; Naik, N.Y. Spinoffs and information. J. Financ. Intermed. 1997, 6, 153-176. [CrossRef]

28. Fryges, H.; Wright, M. The origin of spin-offs: A typology of corporate and academic spin-offs. Small Bus. Econ. 2014, 43, 245-259. [CrossRef]

29. Stonham, P. Demergers and the Hanson experience. Part two: Demerger tactics. Eur. Manag. J. 1997, 15, 413-422. [CrossRef]

30. Schipper, K.; Smith, A. Effects of recontracting on shareholder wealth: The case of voluntary spin-offs. J. Financ. Econ. 1983, 12, 437-467. [CrossRef]

31. Cusatis, P.J.; Miles, J.A.; Randall Woolridge, J.R. Restructuring through spinoffs: The stock market evidence. J. Financ. Econ. 1993, 33, 293-311. [CrossRef]

32. Prashant, M. Do Demergers and Spin-Offs Create Value for Shareholders? 2018. Available online: https://www.sharesight.com/ blog/do-demergers-and-spin-offs-create-value-for-shareholders/ (accessed on 27 May 2021).

33. Corporate Restructuring. Corporate Restructuring, Insolvency, Liquidation \& Winding-Up. 2019. Available online: https://www. icsi.edu/media/webmodules/Corporate_Restructuring_Insolvency_LiquidationandWindingUp.pdf (accessed on 27 May 2021).

34. Baba, C.M.; Duguleană, C.; Dincă, M.S.; Duguleană, L.; Dincă, G. The Demerger Impact upon Sustainable Development of Economic Entities: Evidence from Romania. Sustainability 2021, 13, 8316. [CrossRef]

35. Romanian Companies. Available online: https://www.listafirme.ro (accessed on 4 January 2021).

36. National Trade Register Office. Available online: https://www.onrc.ro (accessed on 29 April 2021).

37. Grewatsch, S.; Kleindienst, I. When does it pay to be good? Moderators and mediators in the corporate sustainability-Corporate financial performance relationship: A critical review. J. Bus. Ethics 2017, 145, 383-416. [CrossRef]

38. Peloza, J. The challenge of measuring financial impacts from investments in corporate social performance. J. Manag. 2009, 35, 1518-1541. [CrossRef]

39. Lassala, C.; Orero-Blat, M.; Ribeiro-Navarrete, S. The financial performance of listed companies in pursuit of the Sustainable Development Goals (SDG). Econ. Res. Ekon. Istraživanja 2021, 34, 427-449. [CrossRef]

40. Inoue, Y.; Lee, S. Effects of different dimensions of corporate social responsibility on corporate financial performance in tourismrelated industries. Tour. Manag. 2011, 32, 790-804. [CrossRef]

41. Makni, R.; Francoeur, C.; Bellavance, F. Causality between corporate social performance and financial performance: Evidence from Canadian firms. J. Bus. Ethics 2009, 89, 409-422. [CrossRef]

42. Baird, P.L.; Geylani, P.C.; Roberts, J.A. Corporate social and financial performance re-examined: Industry effects in a linear mixed model analysis. J. Bus. Ethics 2012, 109, 367-388. [CrossRef]

43. Wang, T.; Bansal, P. Social responsibility in new ventures: Profiting from a long-term orientation. Strateg. Manag. J. 2012, 33, 1135-1153. [CrossRef]

44. Khatab, H.; Masood, M.; Zaman, K.; Saleem, S.; Saeed, B. Corporate Governance and Firm Performance: A Case study of Karachi Stock Market. Int. J. Trade Econ. Financ. 2011, 2, 39-43. [CrossRef]

45. Kharatyan, D.; Lopes, J.C.; Nunes, A. Determinants of Return on Equity: Evidence from Nasdaq 100. Digital Repository, FINANCE. Instituto Politécnico de Bragança. 2017, XXVII Jornadas Hispano-Lusas Gestión Científica. Available online: http: / / hdl.handle.net/10198/21197 (accessed on 6 April 2021).

46. Pinsent, W. Decoding DuPont Analysis. 2021. Available online: https://www.investopedia.com/articles/fundamental-analysis/ 08/dupont-analysis.asp (accessed on 11 December 2021).

47. Furhmann, R. Return on Equity (ROE) vs. Return on Assets (ROA): What's the Difference? 2021. Available online: https://www. investopedia.com/ask/answers/070914/what-are-main-differences-between-return-equity-roe-and-return-assets-roa.asp (accessed on 10 December 2021).

48. Hsu, L.T.; Jang, S. The postmerger financial performance of hotel companies. J. Hosp. Tour. Res. 2007, 31, 471-485. [CrossRef]

49. Dickerson, A.P.; Gibson, H.D.; Tsakalotos, E. The impact of acquisitions on company performance: Evidence from a large panel of UK firms. Oxf. Econ. Pap. 1997, 49, 344-361. [CrossRef]

50. Meeks, G. Disappointing Marriage: A Study of the Gains from Merger; Cambridge University Press: Cambridge, UK, 1977. 
51. Greene, W. Econometric Analysis of Panel Data. 2006. Available online: https://people.stern.nyu.edu/wgreene/Econometrics/ PanelDataNotes.htm (accessed on 28 November 2020).

52. Park, H.M. Practical Guides to Panel Data Modelling: A Step by Step Analysis Using Stata. 2011. Available online: https: //www.iuj.ac.jp/faculty/kucc625/method/panel/panel_iuj.pdf (accessed on 2 December 2020).

53. Podestà, F. Recent Developments in Quantitative Comparative Methodology: The Case of Pooled Time Series Cross-Section Analysis. DSS Papers Soc. 2002, 3, 5-44.

54. Poi, B.P. From the help desk: Swamy's random-coefficients model. Stata J. 2003, 3, 302-308. [CrossRef]

55. Kennedy, P. Guide to Econometrics; Wiley-Blackwell: New York, NY, USA, 2008.

56. Mohammadi, T. Relative Performance of Components Variance Estimators in Random Effects Models. Iran. J. Econ. Res. 2012, 17, 83-98.

57. Baltagi, B.H. Econometric Analysis of Panel Data; John Wiley: New York, NY, USA, 2001.

58. Corbae, D.; Ouliaris, S. Extracting Cycles from Nonstationary Data. In Econometric Theory and Practice. Frontiers of Analysis and Applied Research; Cambridge University Press: Cambridge, UK, 2012; pp. 167-177. 